\title{
Large-scale overview of the summer monsoon over West Africa during the AMMA field experiment in 2006
}

S. Janicot ${ }^{1}$, C. D. Thorncroft ${ }^{2}$, A. Ali ${ }^{3}$, N. Asencio ${ }^{4}$, G. Berry ${ }^{2}$, O. Bock ${ }^{5}$, B. Bourles ${ }^{6}$, G. Caniaux ${ }^{4}$, F. Chauvin ${ }^{4}$,

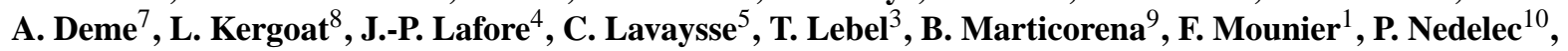

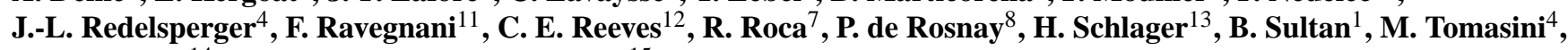
A. Ulanovsky ${ }^{14}$, and ACMAD forecasters team ${ }^{15}$

${ }^{1}$ Institut de Recherches pour le Développement, Laboratoire d'Océanographie et du Climat: Expérimentation et Analyses

Numériques, Paris, France

${ }^{2}$ University of Albany, Department of Earth and Atmospheric Sciences, Albany, NY, USA

${ }^{3}$ Institut de Recherches pour le Développement, Laboratoire d'étude des Transferts en Hydrologie et Environnement, Grenoble, France

${ }^{4}$ Meteo-France, Centre National de la Recherche Météorologique, Toulouse, France

${ }^{5}$ Université Pierre et Marie Curie, Service d'Aéronomie, Paris, France

${ }^{6}$ Inst. de Recherches pour le Développement, Lab. d'Etudes en Géophysique et Océanographie Spatiale, Brest, France

${ }^{7}$ Centre National de la Recherche Scientifique, Laboratoire de Météorologie Dynamique, Paris, France

${ }^{8}$ Centre National de la Recherche Scientifique, Centre d'Etudes Spatiale de la Biosphère, Toulouse, France

${ }^{9}$ Centre National de la Recherche Scientifique, Laboratoire Inter-universitaire des Systèmes Atmosphériques, Créteil, France

${ }^{10}$ Centre National de la Recherche Scientifique, Laboratoire d'Aérologie, Toulouse, France

${ }^{11}$ Istituto di Scienze dell'Atmosfera e del Clima - Consiglio Nazionale di Ricerca Italiano, Bologna, Italy

${ }^{12}$ University of East Anglia, School of Environmental Sciences, Norwich, UK

${ }^{13}$ Deutsches Zentrum fuer Luftund Raumfahrt, Institut fuer Physik der Atmosphaere, Oberpfaffenhofen-Wessling, Germany

${ }^{14}$ Central Aerological Observatory, Moscow, Russia

${ }^{15}$ African Centre of Meteorological Application for Development, Niamey, Niger

Received: 21 November 2007 - Revised: 18 June 2008 - Accepted: 3 July 2008 - Published: 5 September 2008

\begin{abstract}
The AMMA (African Monsoon Multidisciplinary Analysis) program is dedicated to providing a better understanding of the West African monsoon and its influence on the physical, chemical and biological environment regionally and globally, as well as relating variability of this monsoon system to issues of health, water resources, food security and demography for West African nations. Within this framework, an intensive field campaign took place during the summer of 2006 to better document specific processes and weather systems at various key stages of this monsoon season. This campaign was embedded within a longer observation period that documented the annual cycle of surface and atmospheric conditions between 2005 and 2007. The present paper provides a large and regional scale overview of the 2006 summer monsoon season, that includes consideration of of the convective activity, mean atmospheric circu-
\end{abstract}

lation and synoptic/intraseasonal weather systems, oceanic and land surface conditions, continental hydrology, dust concentration and ozone distribution. The 2006 African summer monsoon was a near-normal rainy season except for a large-scale rainfall excess north of $15^{\circ} \mathrm{N}$. This monsoon season was also characterized by a 10-day delayed onset compared to climatology, with convection becoming developed only after 10 July. This onset delay impacted the continental hydrology, soil moisture and vegetation dynamics as well as dust emission. More details of some less-well-known atmospheric features in the African monsoon at intraseasonal and synoptic scales are provided in order to promote future research in these areas.

Keywords. Meteorology and atmospheric dynamics (Climatology; Precipitation; Tropical meteorology)

Correspondence to: S. Janicot

(serge.janicot@locean-ipsl.upmc.fr)

Published by Copernicus Publications on behalf of the European Geosciences Union. 


\section{Introduction}

The AMMA (African Monsoon Multidisciplinary Analysis) program aims at enhancing our understanding of the West African monsoon and its underlying physical, chemical and biological processes. This enhanced knowledge of the processes involved in the establishment and variability of the monsoon will be used to improve our capacity to predict it and evaluate the impacts on land-productivity, management of water resources and public health. The objective is to provide societies in Africa with improved tools to manage their dependence on environmental conditions. In the framework of AMMA a dense observational network was established both as routine and campaign-based facilities. The aim of these observations was to provide a complete picture of the physical, chemical and biological processes over the ocean, the continent and in the atmosphere. The base network was established over the years leading up to the special observing period in the summer of 2006 and covered surface states and surface flux monitoring in a number of catchments over the climatic gradient of the region. The upper-air sounding network was upgraded and enhanced to improve the data available for operational weather forecasting. During 2006 AMMA supported a large field campaign (Special Observations Period; SOP) to cover the dry season (January-February; SOP0), the monsoon onset (1 June-15 July; SOP1), the peak of the monsoon (15 July-15 September; SOP2) and the late monsoon (15-30 September; SOP3). The enhancements to the observing system in 2006 included balloon borne instruments, 2 doppler weather radars in Benin and Niger, a lightning network over northern Benin, 3 research ships in the Atlantic and 6 research aircraft stationed in Niamey, Ouagadougou and Cape Verde. Many of the "peak of the monsoon" observations were dedicated to the intense mesoscale convective systems which are generated in the region and travel to the West. Their impact on the circulation in the troposphere and lower stratosphere, the water cycle and the transport of trace gases and aerosols has been observed at different stages of the life cycle of these systems.

An overview of the 2006 summer monsoon season at large and regional scales is presented here covering the topics of the atmospheric dynamics and its links with the evolution of sea surface temperatures in the tropical Atlantic, the activity of the mesoscale convective systems and the synoptic scale weather systems, the continental hydrological cycle, the soil moisture conditions and the evolution of the vegetation cover, atmospheric chemistry and the Saharan aerosols content in the atmosphere. More details on some little-known atmospheric features in the African monsoon at intraseasonal and synoptic scales are provided in order to promote future research in these areas and because these timescales are particularly relevant for end-users like farmers. These preliminary results will be more extensively investigated in future papers.

Ann. Geophys., 26, 2569-2595, 2008

\section{Interannual variability}

\subsection{Precipitation and convection}

Figure 1a shows the anomalous May-September 2006 rainfall field north of $10^{\circ} \mathrm{N}$ with respect to the 2001-2005 average and Fig. 1b displays the corresponding standardized May-September Sahelian rainfall anomaly index relative to the long-term period 1905-2006. The two horizontal red lines in Fig. 1a delineate the Sahel area approximately between the 200 and $500 \mathrm{~mm}$ average isohyets, and the vertical red line separates the west from the east of Sahel. With respect to the 2001-2005 average, in 2006 the Sahel was a bit drier over its southern part and much wetter over its northern part, which leads to a regional index value near the 2001-2005 average (see Fig. 1b). The year 2006 is in the recent rainfall recovery period following the long-term drought, which began in 1968 and reached its lowest rainfall amount in 1984. Since 1985 summer precipitation anomalies have been still negative but closer to the long-term mean. However the east and the west of Sahel rainfall anomaly time series are not so similar especially after 1987 where western Sahel rainfall anomalies are always negative while eastern Sahel rainfall anomalies are either negative or positive (not shown). This is the case in summer 2006 where western anomalies are negative and eastern anomalies positive.

Another way to document the interannual variability of the convective activity over West Africa is to consider the anomaly field of out-going longwave radiation (OLR; Liebmann and Smith, 1996). Figure 2 displays these data for July-September 2006 relative to the period 1990-2005. A meridional dipole pattern is evident with lower (higher) values north (south) of $12^{\circ} \mathrm{N}$ consistent with an anomalous northward location of the ITCZ relative to the 1990-2005 average around $10^{\circ} \mathrm{N}$, and the rainfall anomaly pattern presented in Fig. 1. This is associated with positive sea surface temperature (SST) anomalies in the tropical Atlantic (see below) with no significant and persistent SST anomalies present in other basins. Thus, while globally the seasonal rainfall over the Sahel was not far from the average of recent years, (see Fig. 1b), the latitudinal gradient which is a main feature of the average rain field was smoothed out due to the large-scale rainfall excess of more than $60 \%$ north of $15^{\circ} \mathrm{N}$ (see Fig. 1a).

\subsection{Monthly atmospheric fields over Africa}

Figures 3 to 5 show the 1979-1999 averaged wind fields at $925 \mathrm{hPa}, 600 \mathrm{hPa}$ and $200 \mathrm{hPa}$ in June, July, August and September, together with the same fields for 2006. At $925 \mathrm{hPa}$ (Fig. 3 left) the black line over West Africa represents the zero-isoline of the zonal component to delineate the domain of the monsoon winds (i.e. westerly component). Over the northern Sahel this isoline characterizes the location of the Inter-Tropical Discontinuity (ITD) which 


\section{Anomalies 2006 with respect to average 2001-2005 (\%)}
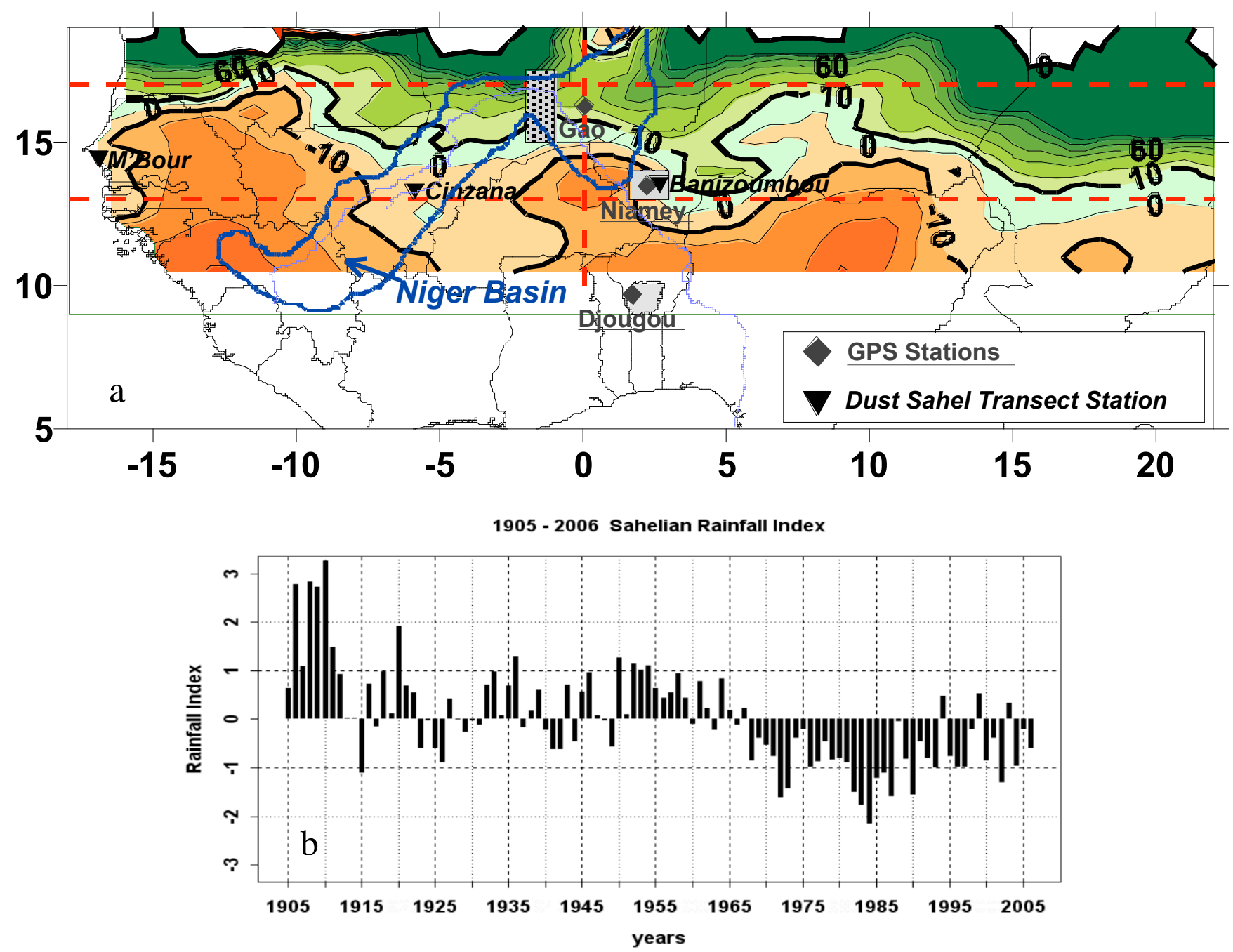

Fig. 1. (a) May-September 2006 rainfall anomalies relative to the period 2001-2005 expressed in \%. The grey areas represent the three meso-sites near Djougou, Niamey and Gao. The dark blue contour indicates the limits of the Niger Basin at Niamey where the area of the catchment is $860000 \mathrm{~km}^{2}$. The other stations (GPS and dust networks) are also indicated. (b) The corresponding May-September Sahelian rainfall index, expressed in normalized anomalies, is computed from 1905 to 2006 by averaging rainfall data between the two horizontal red lines. Source of the data: AGRHYMET.

is the confluence of the southwesterly monsoon winds with the northeasterly dry Harmattan winds. The monsoon winds are controlled by the pressure gradient between the low pressures of the Saharan heat low centred along the ITD and the oceanic high pressures of the Santa Helena anticyclone. The Harmattan winds are controlled by the pressure gradient between the Saharan heat low and the Libyan and Azores anticyclones. In June the ITCZ is centred over the southern coast of West Africa, south of $10^{\circ} \mathrm{N}$ and corresponds to the last part of the first rainy season over the Guinea coast region (see below). At this stage the spatial extension of the monsoon winds is limited and the ITD is positioned between $15^{\circ} \mathrm{N}$ and $20^{\circ} \mathrm{N}$ with its northernmost latitude between $0^{\circ} \mathrm{W}$ and $5^{\circ} \mathrm{E}$. In July the ITCZ is shifted to the north reaching a quasi-stable state around $10^{\circ} \mathrm{N}$ (see below) and the area of westerly winds extend over land and over the tropical Atlantic between $5^{\circ} \mathrm{N}$ and $15^{\circ} \mathrm{N}$, the ITD reaching $20^{\circ} \mathrm{N}$, its northernmost latitude. The westerly wind speed increases over West Africa. In August the monsoon is fully developed consistent with the highest pressures in the southern tropical Atlantic and the northernmost location of the Saharan heat low over land. The ITCZ is still around $10^{\circ} \mathrm{N}$ but with increased precipitation. The westerly wind area has its largest extension, especially over the northern tropical Atlantic where westerly moisture advection inland reaches its seasonal maximum. In September the westerly wind area 


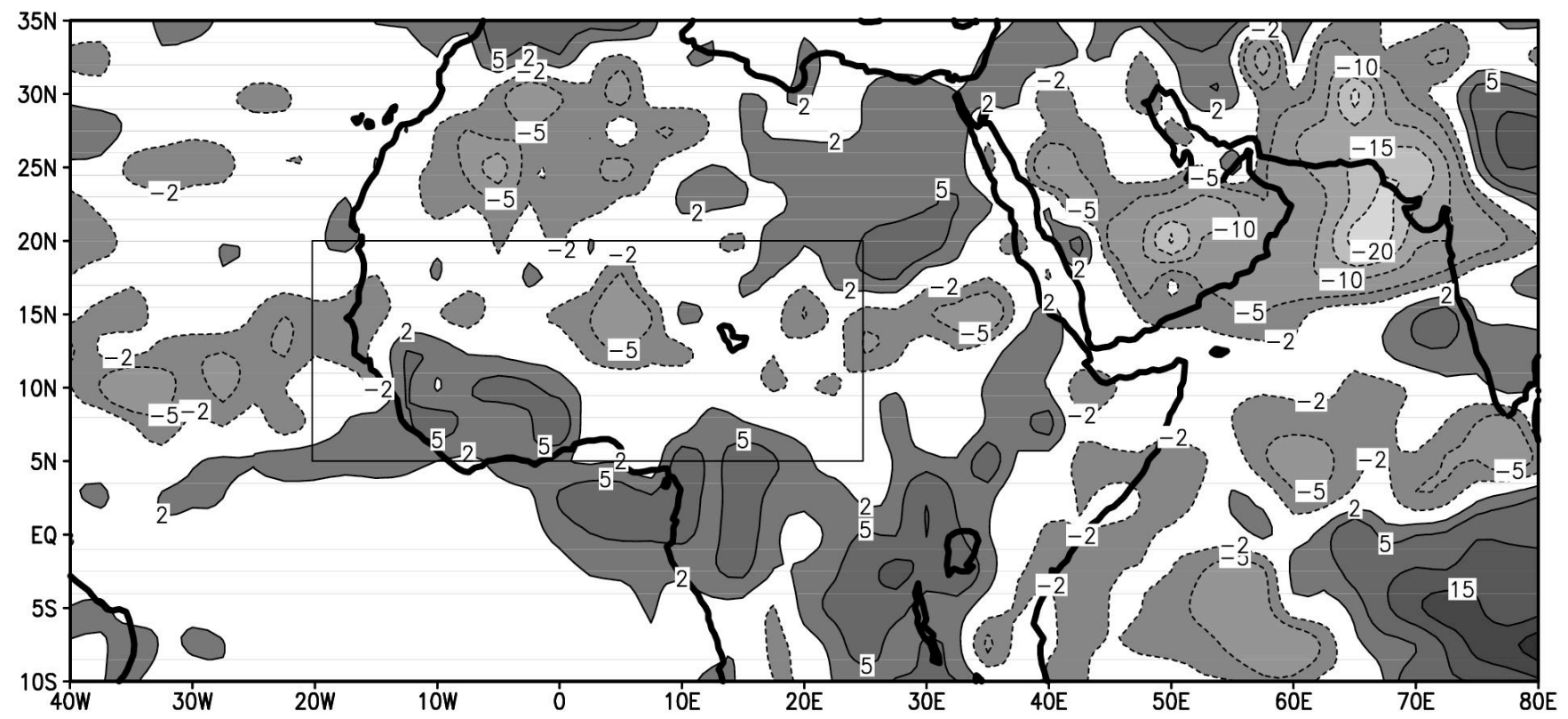

Fig. 2. July-September 2006 OLR anomalies relative to 1990-2005. Negative (positive) values in the ITCZ area means enhanced (weakened) convection. The box locates the domain of Fig. 1a.

does not change significantly but the westerly wind speed decreases drastically. This is the last part of the fully-developed monsoon season. In 2006 (Fig. 3 right) compared to the climatological mean described above, the monsoon activity was less developed in June, had a similar extension in July and had a stronger westerly wind field in August and September with an increased westward extension over the northern tropical Atlantic.

The $600 \mathrm{hPa}$ level (Fig. 4 left) is the level of the heart of the African easterly Jet (AEJ) which is embedded in the southern part of the high pressure cell of the Libyan anticyclone located above the Saharan heat low. The AEJ maintenance is mainly controlled by the low/mid-levels transverse circulation induced by the heat low (Thorncroft and Blackburn, 1999). This circulation, as well as the AEJ, has its highest intensity and spatial extension in June before the monsoon onset (Sultan and Janicot, 2003). The core of the jet is located between $5^{\circ} \mathrm{N}-10^{\circ} \mathrm{N}$ and $10^{\circ} \mathrm{W}-10^{\circ} \mathrm{E}$ with a mean highest speed of $14 \mathrm{~m} \mathrm{~s}^{-1}$. In July and August the AEJ moves to the north, and is oriented along a southeast-northwest axis around $15^{\circ} \mathrm{N}$ over the western coast of West Africa. Its core speed at this time decreases to $10 \mathrm{~m} \mathrm{~s}^{-1}$. It retreats southward in September and its speed increases to $12 \mathrm{~m} \mathrm{~s}^{-1}$. Another core is noticeable south of the equator in September independent of the AEJ and has been described previously by Grist and Nicholson (2001). In 2006 (Fig. 4 right) the AEJ had a larger extension in June but with a weaker core. Its speed was higher also in July west of $0^{\circ} \mathrm{W}$ and weaker than the mean east of $0^{\circ} \mathrm{W}$. It was stronger in August and well marked along its whole structure. In September it was still well coherent and located slightly northward with respect to the mean. The southern core over Central Africa was also stronger from July to September and more extended over the ocean than the mean field.

At $200 \mathrm{hPa}$ (Fig. 5 left) the high-level anticyclonic structure, which is the sign of the Indian and African monsoons induces an easterly wind field on its southern flank with a core speed greater than $20 \mathrm{~m} \mathrm{~s}^{-1}$ centred over the Indian Ocean. This jet, the Tropical Easterly Jet (TEJ), enhances in July and August in parallel with the monsoon activity. In particular its westward extension over Africa is reactivated and a maximum of $14 \mathrm{~m} \mathrm{~s}^{-1}$ is evident between $10^{\circ} \mathrm{W}$ and $30^{\circ} \mathrm{W}$. It decreases significantly in September over its whole domain. In 2006 (Fig. 5 right) the TEJ was weaker over the Indian sector during the whole summer compared to the mean (the Indian monsoon was a bit more active over northeastern India but a bit weaker over central India and highly weaker over the equatorial Indian ocean and Indonesia compared to the 1979-1999 mean; not shown). Over West Africa, after a period of weaker wind speeds in June, the TEJ extended further to the west in July and displayed higher speeds in August and September, consistently with a bit higher active monsoon season compared to the 1979-1999 mean (not shown).

It is worth noticing that during the summer of 2006 there was a notable increase in the amount of launched radiosondes (Parker et al., 2008) at a rate not seen since the GATE field campaign in 1974 and the WAMEX campaign in 1979. A high number of them were transmitted to the GTS and were assimilated at NCEP. It is possible that these additional data influence the comparisons made here between 2006 and the 

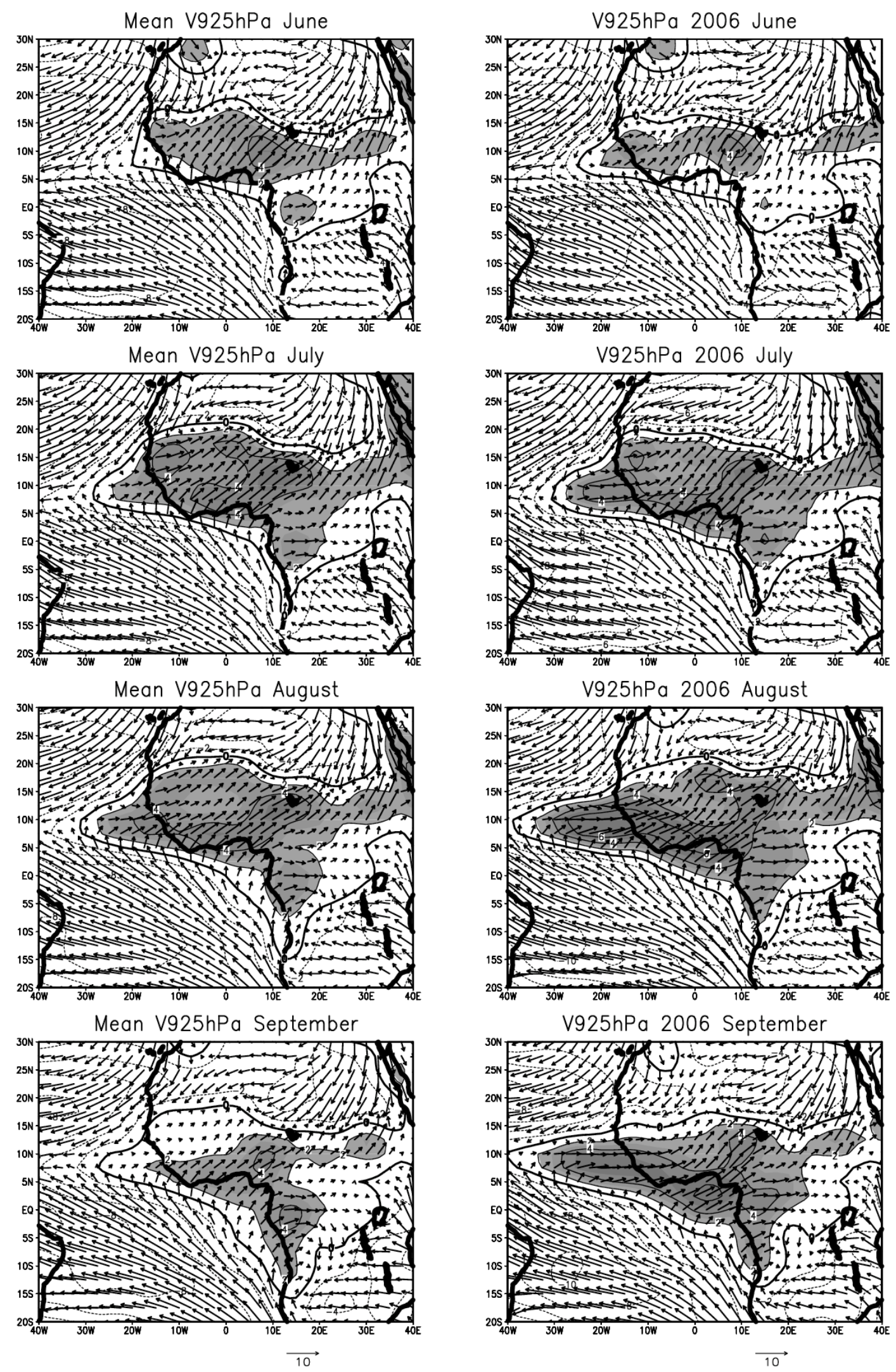

Fig. 3. Left: 1979-1999 averaged wind fields at $925 \mathrm{hPa}$, in June, July, August, September from NCEP. Right: Same wind fields but for 2006. Shaded areas for westerly wind component higher than $2 \mathrm{~ms}^{-1}$. The vector scale is displayed. 

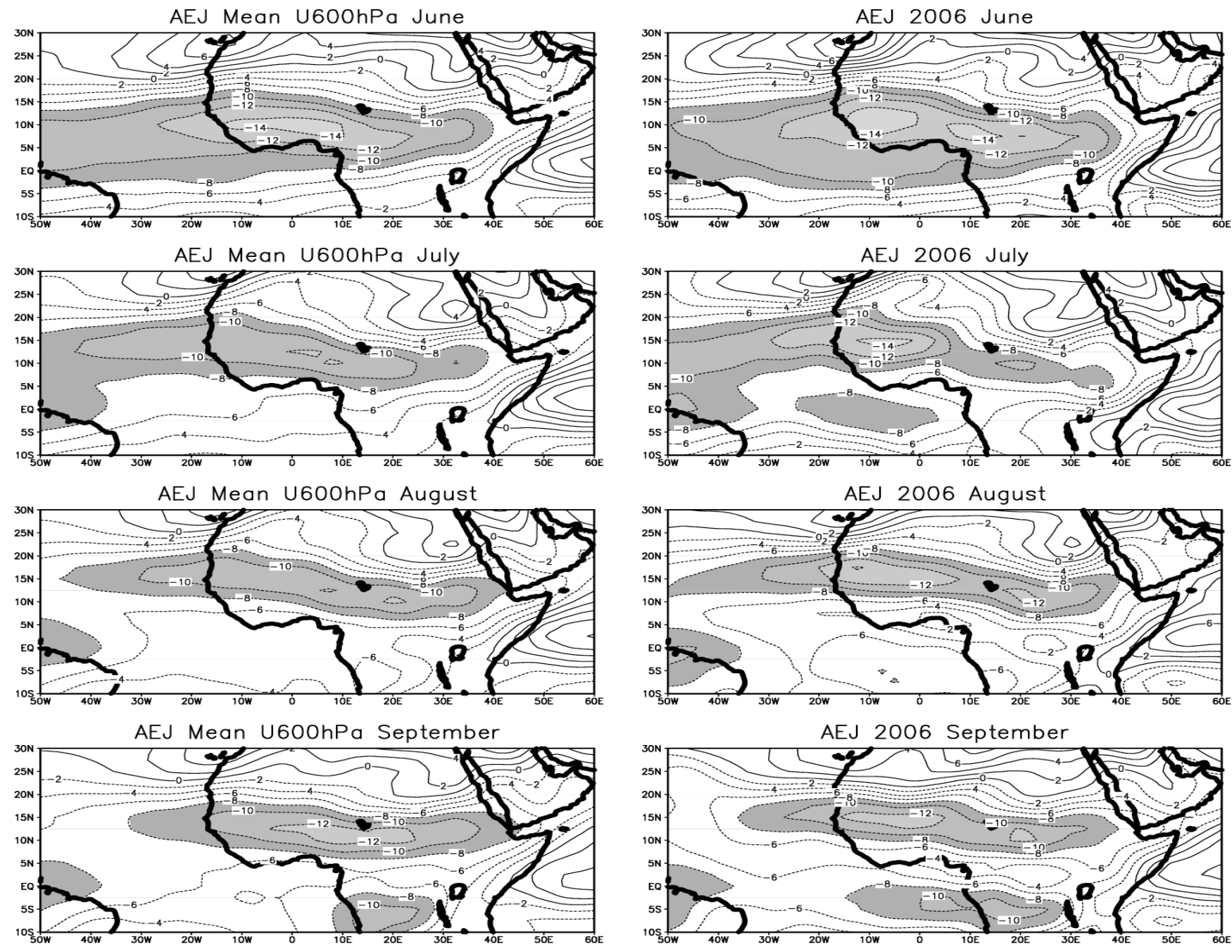

Fig. 4. Left: 1979-1999 averaged zonal wind fields at $600 \mathrm{hPa}$, in June, July, August, September from NCEP. Right: Same wind fields but for 2006. Shaded areas for easterly wind component higher than $8 \mathrm{~ms}^{-1}$.

climatology, some of the anomalies being due to better analyses than before and not "real" anomalies.

\section{The annual cycle and the monsoon onset}

\subsection{The Inter-Tropical Convergence Zone}

The onset stage of the African summer monsoon is linked to an abrupt latitudinal shift of the ITCZ from a quasi-stationary location at $5^{\circ} \mathrm{N}$ in May-June to a second quasi-stationary location at $10^{\circ} \mathrm{N}$ in July-August. This stage corresponds to major changes in the atmospheric circulation over West Africa linked to the full development of the summer monsoon system (Sultan and Janicot, 2003). This abrupt shift occurs mostly between $10^{\circ} \mathrm{W}$ and $5^{\circ} \mathrm{E}$ where a meridional land-sea contrast exists and it is also generally characterized by a temporary decrease of convection over the whole of
West Africa. During the 1968-2005 period, the mean date of the monsoon onset was 24 June with a standard deviation of 8 days.

Figure 6 depicts the latitude-time cross-section of the OLR field in 2006 averaged between $10^{\circ} \mathrm{W}$ and $10^{\circ} \mathrm{E}$ and with a moving average of \pm 3 days to filter the high-frequency fluctuations. Only values weaker than $230 \mathrm{~W} \mathrm{~m}^{-2}$ are displayed to focus on the high convective activity in the ITCZ. After rather weak convective activity in winter, the first rainy season over the Guinean Coast (the coast line is located at $5^{\circ} \mathrm{N}$ ) begins around mid-April with an intensification of convective activity during the second half of April and most of May. This was followed by a temporary weakening around the end of May and a recovery of convective activity in the first half of June. Convection weakens again from approximately 25 June to 10 July, which corresponds to the typical transition phase of the monsoon onset (Sultan and Janicot, 
TEJ Mean U200hPa June

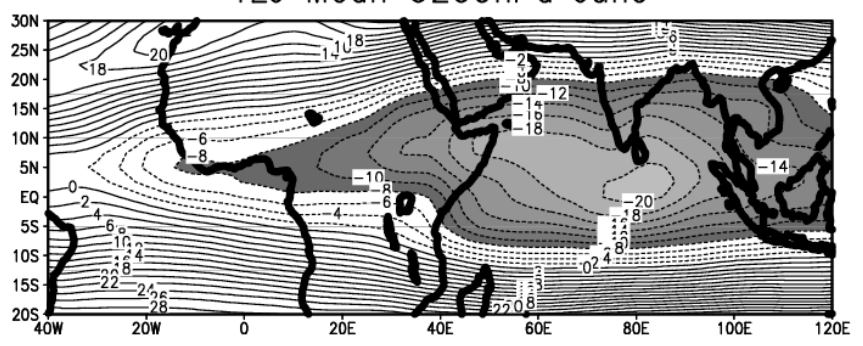

TEJ Mean U200hPa July

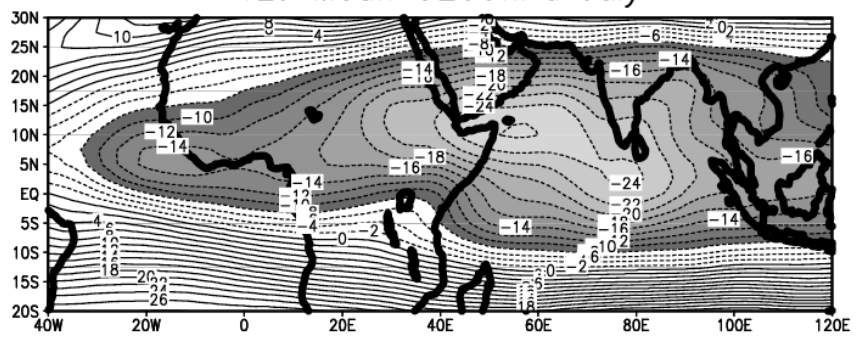

TEJ Mean U200hPa August

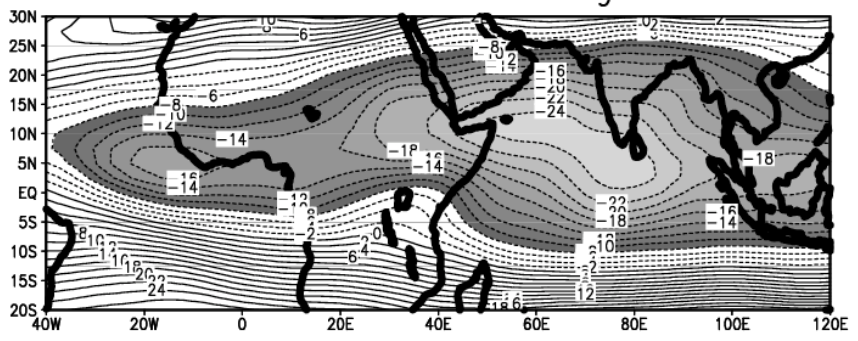

TEJ Mean U200hPa September

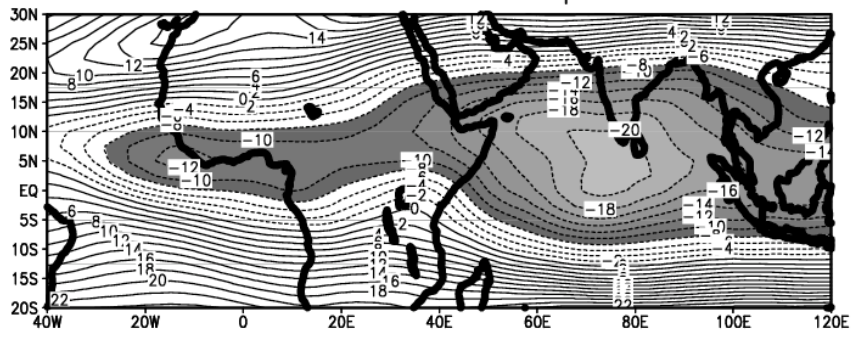

TEJ 2006 June

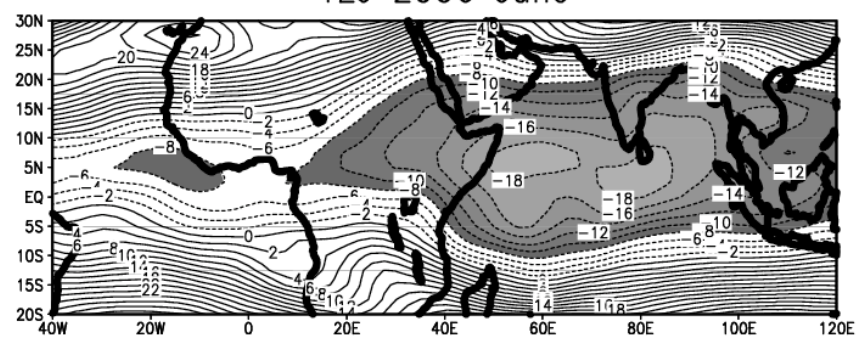

TEJ 2006 July

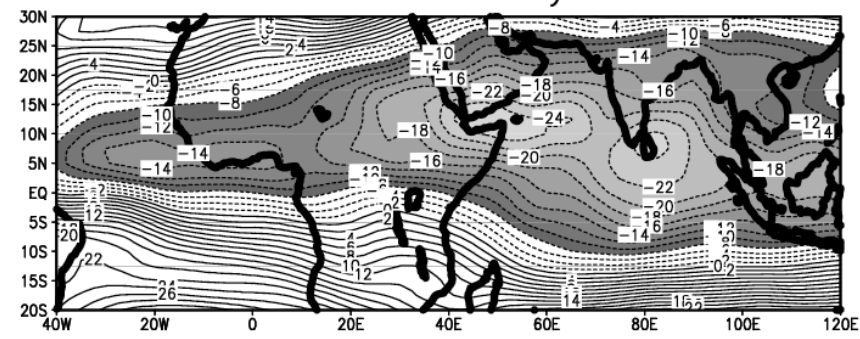

TEJ 2006 August

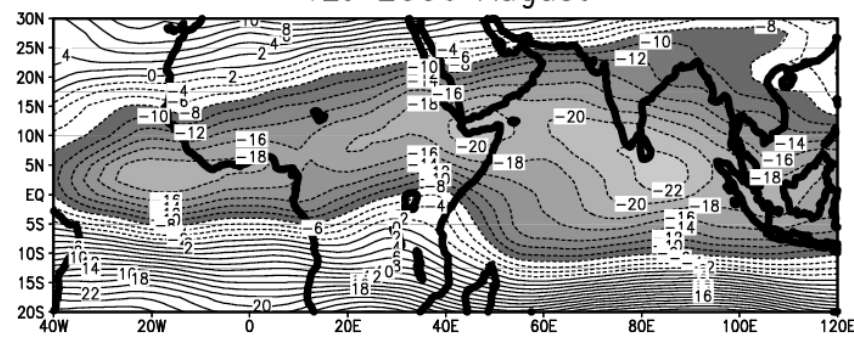

TEJ 2006 September

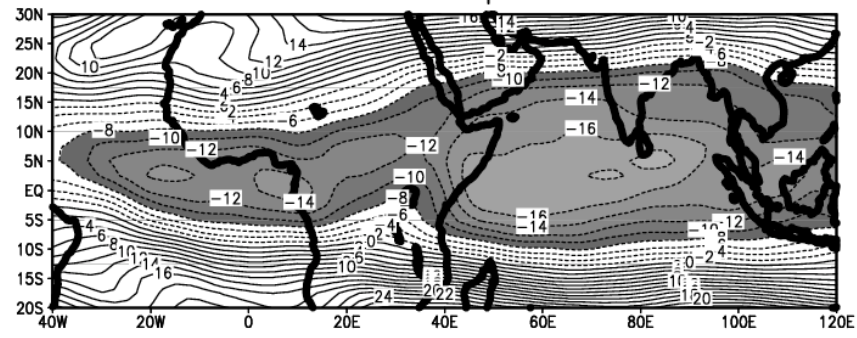

Fig. 5. Left: 1979-1999 averaged zonal wind fields at 200 hPa, in June, July, August, September from NCEP. Right: Same wind fields but for 2006. Shaded areas for easterly wind component higher than $8 \mathrm{~ms}^{-1}$.

2003), followed by the installation of the monsoon and convection over the Sahelian latitudes with the centre of gravity of the ITCZ located between $10^{\circ} \mathrm{N}$ and $12^{\circ} \mathrm{N}$ during the whole summer. This transition phase is centred on 3 July, ten days after the mean onset date, and corresponds to a cumulative probability of occurrence of $10 \%$ (i.e. $10 \%$ on the onsets occurred on and after 3 July.
In order to monitor operationally the seasonal progression towards the onset stage of the African monsoon, an Onset Index (OI) has been defined to detect the northward migration of the ITCZ from the Guinean Coast to the Sahelian latitudes. To do so, two standardized OLR indices have been computed using a 5-day mean over $10^{\circ} \mathrm{W}-10^{\circ} \mathrm{E}$ : a Northern Index (NI) between $7.5^{\circ} \mathrm{N}$ and $20^{\circ} \mathrm{N}$, and a Southern Index (SI) between $0^{\circ} \mathrm{N}$ and $7.5^{\circ} \mathrm{N}$. The $\mathrm{OI}$ is defined as the 


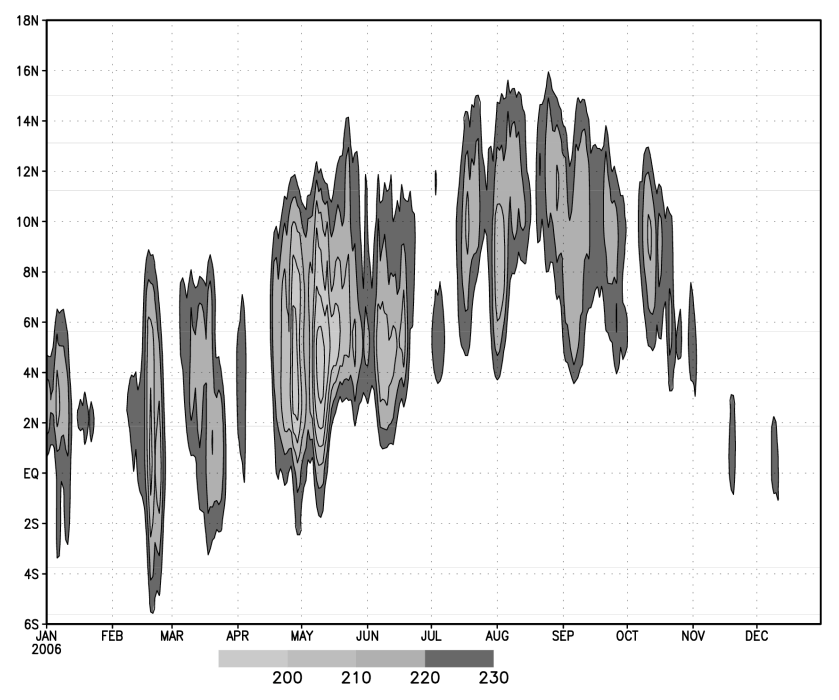

Fig. 6. Time-latitude cross-section of the OLR field averaged on $10^{\circ} \mathrm{W}-10^{\circ} \mathrm{E}$ in 2006 . A moving average on \pm 3 days have been applied to smooth the signal. The coastline is located approximately at $5^{\circ} \mathrm{N}$. Only values lower than $230 \mathrm{~W} \mathrm{~m}^{-2}$ are shaded.

difference between the NI and SI. It is presented in Fig. 7 with a reversed sign in order to be interpreted as a rainfall signal (positive values when the ITCZ is at its northern location and vice-versa). The onset date probability function is represented by the shaded vertical bars in Fig. 7, the more probable onset dates corresponding to the higher density of the shading. These $\mathrm{x}$-axis labels are expressed in pentads from the beginning of the year. The black line depicts the mean index over the period 1979-2000 and the thin line the index in 2006. The curve of the mean index shows a smooth transition from negative values (when the ITCZ is located over the Guinean Coast) to positive values (when the ITCZ is located over the Sahelian latitudes) except for a rapid northward acceleration after pentad number 36 (that is just after the onset date of 24 June). The curve for 2006 shows an evolution similar to the mean except it is noisier. The index first peaks with a positive value during pentad 29 (that is 20-25 May) but retreats quickly to negative values. This event being short and located outside of the onset occurrence probability period (represented by the vertical bars) can be considered as a bogus onset. It can be seen in Fig. 6 as a temporary northward extension of the ITCZ during the second half of May. The causes of this bogus onset will be analyzed in a later paper. The onset index reached positive values again during pentad 35 (19-23 June) and remained weak until pentad 38 (5-9 July) when it increased drastically. Based on this analysis we can note that the convective activity over the Sahel begins around 10 July at the regional scale, that is, with a mean delay of 10 days relative to the mean installation of the African summer monsoon. The index remained anomalously high during the late summer period consistent with the slighty higher than average convective activity then.
More detailed diagnostics of the June-September convective activity are presented in Fig. 8. Using an automatic tracking algorithm (see Morel and Senesi, 2002) Tomasini et al. (2006) have characterized the convective activity over West Africa by providing a classification of the mesoscale convective systems (MCS) whose surface reaches $5000 \mathrm{~km}^{2}$ at $-40^{\circ} \mathrm{C}$ and based on their mean westward propagation speed and their life duration greater than one hour. Their classification results in four classes of MCS but here we deal only with the fast-moving class (speed faster than $10 \mathrm{~m} \mathrm{~s}^{-1}$ ), which corresponds to the largest systems (typically $30000 \mathrm{~km}^{2}$ ). Their tracks are mainly situated over the Sahel band $\left(10^{\circ} \mathrm{N}-15^{\circ} \mathrm{N}\right)$. This class coincides with the MCS sub-population introduced by Mathon et al. (2002), called Organized Convective Systems, accounting for $90 \%$ of the total rainfall in the Central Sahel region. Figure 8 displays the 5-day average of the fast-moving MCS track numbers per day detected over the Sahelian area $11^{\circ} \mathrm{N}-$ $17^{\circ} \mathrm{N} / 10^{\circ} \mathrm{W}-10^{\circ} \mathrm{E}$. The solid lines represent the evolution of the mean 1996-2006 track numbers as well as the evolution of the mean plus and minus one standard deviation, and the dashed line the 2006 evolution. In accordance with the previous figures the fast-moving MCS activity in 2006 over the Sahel began with a 10-day delay with respect to the 19962006 mean: the track number in 2006 increased markedly after 5 July instead of 25 June for the 1996-2006 mean. After the 10 July the track number was higher than the mean until mid-August and again from 25 August to the end of September, showing a slightly higher than normal overall convective activity in July-September 2006.

\subsection{Daily atmospheric fields over West Africa}

Other diagnostics of the monsoon activity from the NCEP operational analyses have been produced for the summer of 2006 to further highlight the evolution of the monsoon system at the regional scale. This analysis is summarized by two panels in Fig. 9. The above panel displays the averaged $10^{\circ} \mathrm{W}-10^{\circ} \mathrm{E}$ time-latitude evolution of the pressure level of the top of the monsoon layer ( $\mathrm{hPa}$ ) estimated by the level where the mean zonal wind component equals zero from westerly winds below to easterly winds above. The second panel displays the time-latitude evolution of the $925 \mathrm{hPa}$ zonal wind averaged between $25^{\circ} \mathrm{W}-15^{\circ} \mathrm{W}$. After a temporary increase at the beginning of June, both diagrams show an abrupt enhancement of the monsoon at the end of June. The depth of the layer of westerly winds increased over the whole of West Africa at the same time that westerly winds off the coast of West Africa along $10^{\circ} \mathrm{N}$ were enhancing too. This evolution is typical of the beginning of the monsoon onset over West Africa (Sultan and Janicot, 2003). Other monitored NCEP low-levels wind fields over West Africa (zonal wind component, relative vorticity and convection in the Saharan heat low, latitude of the ITD) show a similar timing consistent with a northward progression of the monsoon 


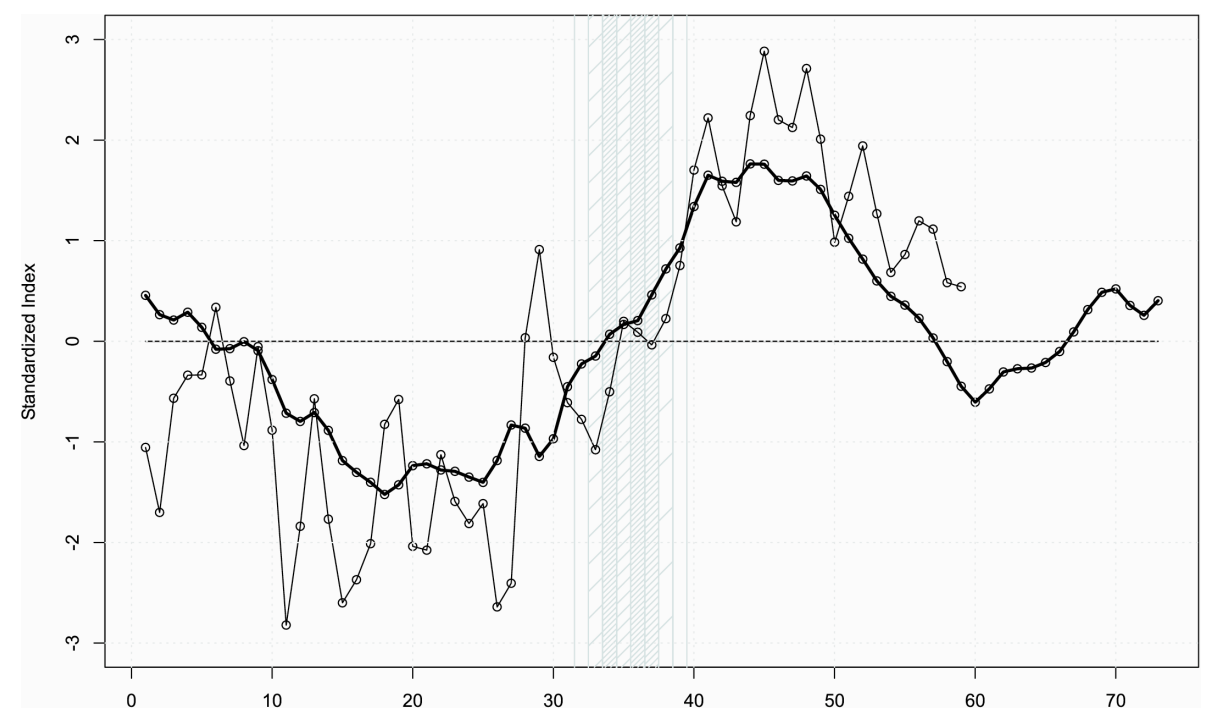

Fig. 7. Time series of the 5-day monsoon index (see text for more details). The black (grey) line represents the averaged index over the period 1979-2000 (the 2006 index). Vertical bars represent the probability function defined in Sultan and Janicot (2003). The x-axis labels are expressed in pentads.

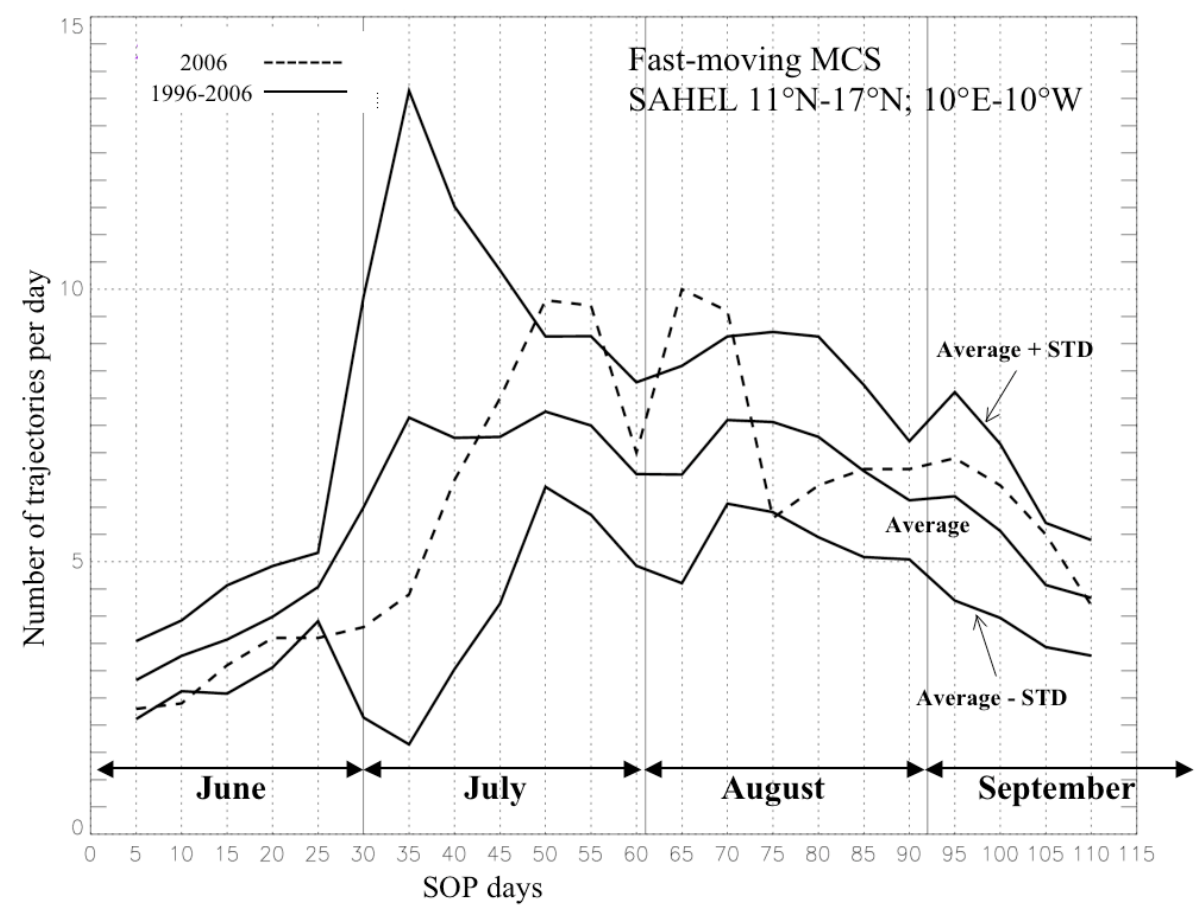

Fig. 8. Five-day average of $\mathrm{C} 3+\mathrm{C} 4 \mathrm{MCS}$ tracks numbers per day detected over the Sahelian area $11^{\circ} \mathrm{N}-17^{\circ} \mathrm{N} / 10^{\circ} \mathrm{W}-10^{\circ} \mathrm{E}$ including a 10-day running average (see details in the text). The black lines represent the evolution of the mean 1996-2006 track numbers as well as the evolution for the mean plus and minus one standard deviation, and the dashed line the 2006 evolution. The $\mathrm{x}$-axis labels are expressed in days from 1 June.

beginning at the end of June (not shown). However we have seen that the deep convection did not begin to increase significantly before the 5 July, with a delay of about 10 days relative to the mean, and was fully developed around 20 July.
Considering all the elements presented here, we conclude that the dynamical monsoon onset occurred around 25 June (near the mean date) while the transition period characterized by an overall weakening of convection over West Africa 

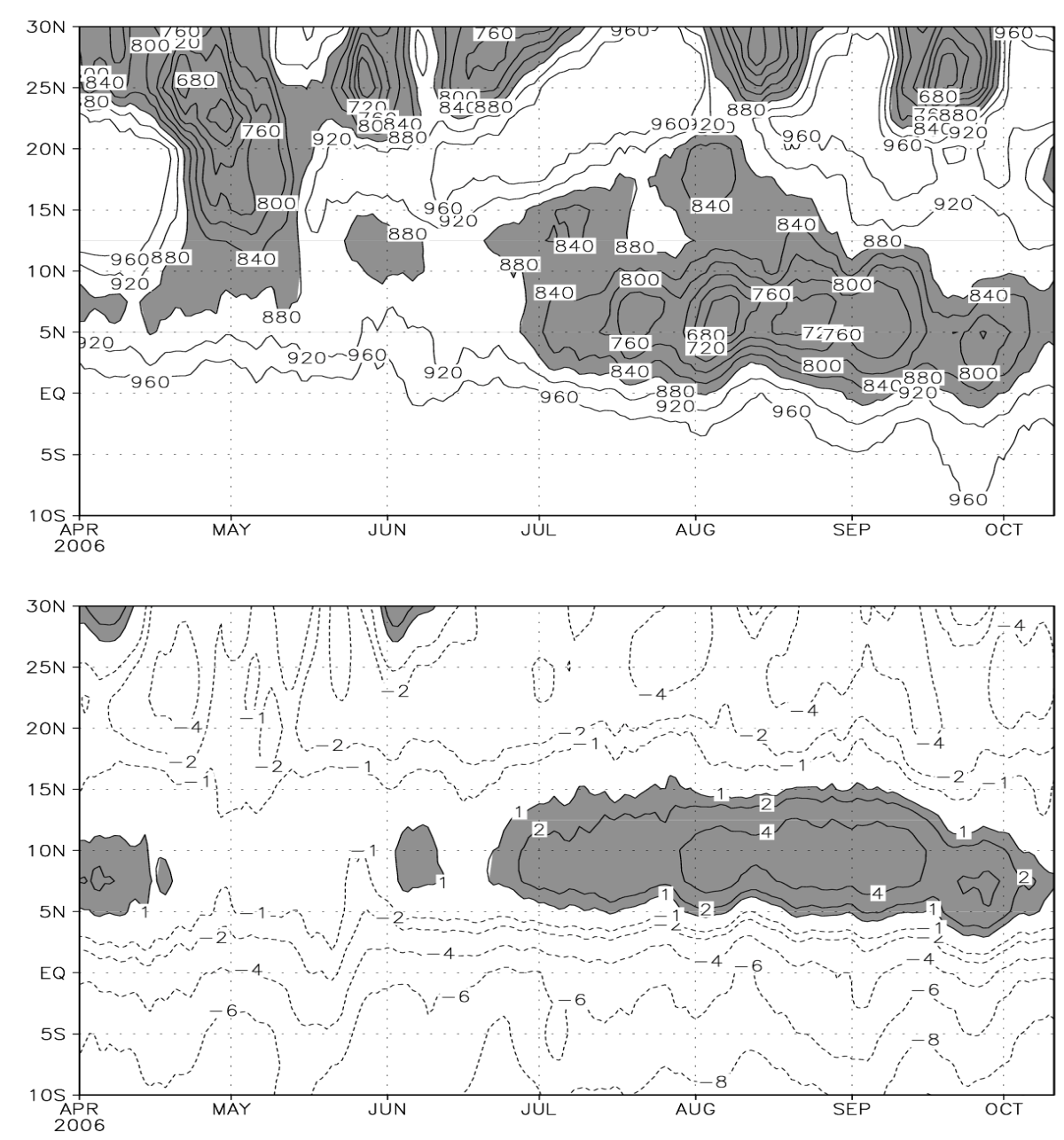

Fig. 9. Top: Averaged $10^{\circ} \mathrm{W}-10^{\circ} \mathrm{E}$ time-latitude evolution of the pressure level of the top of the monsoon layer (hPa) estimated by the level where the mean NCEP zonal wind component equals zero from westerly winds below to easterly winds above. Grey areas for levels lower than $880 \mathrm{hPa}$. Bottom: Averaged $25^{\circ} \mathrm{W}-15^{\circ} \mathrm{W} 925 \mathrm{hPa}$ zonal wind time-latitude evolution. A 11-day moving average has been applied. Grey areas for zonal winds higher than $1 \mathrm{~ms}^{-1}$.

lasted from about the 25 June to the 10 July. The convection began to increase over the Sahel on 5 July with about a 10day delay with respect to the mean. A hypothesis for such a long period of weak convective activity after the monsoon onset will be given in a following section.

Various in situ atmospheric observations are available for the summer of 2006 over West Africa. First the variability of the vertically integrated atmospheric water vapour content was observed by six AMMA Global Positioning System (GPS) sites along two meridional transects over West Africa. One transect consisted of Gao $\left(16.3^{\circ} \mathrm{N}-0^{\circ} \mathrm{E}\right.$; Mali) - Niamey $\left(13.5^{\circ} \mathrm{N}-2.2^{\circ} \mathrm{E}\right.$, Niger $)$ - Djougou $\left(9.7^{\circ} \mathrm{N}-1.7^{\circ} \mathrm{E}\right.$; Benin) (Bock et al., 2007). Each ground-based GPS receiver collected microwave signals transmitted from 8-10 GPS satellites in view. The processing of these signals allows the retrieval of ZTD (zenith tropospheric delay) parameters at $1-\mathrm{h}$ intervals, and in all weather conditions. Pre- cipitable water vapour is derived from the ZTD parameters, surface pressure and mean tropospheric temperature (Bevis et al., 1992). Figure 10 displays the evolution of the water vapour content at the three stations. Red arrows indicate the onset of the first rainy season along the Guinean Coast and green arrows the onset of the summer rainy season over the Sahel. These curves show the step-by-step progression of the water vapour content from winter to summer 2006. The onset of the first rainy season along the Guinean Coast is detected by an abrupt increase of the atmospheric moisture content during the second half of April preceded by a minimum around 10 April when the convective activity was very weak. More to the north at Niamey and Gao this onset is detectable through a peak of the moisture content during the second half of April. This onset may be linked to the southward intrusion of low-level westerly winds from $30^{\circ} \mathrm{N}$ to $5^{\circ} \mathrm{N}$ as seen in Fig. 9 (top). This intrusion was associated with 

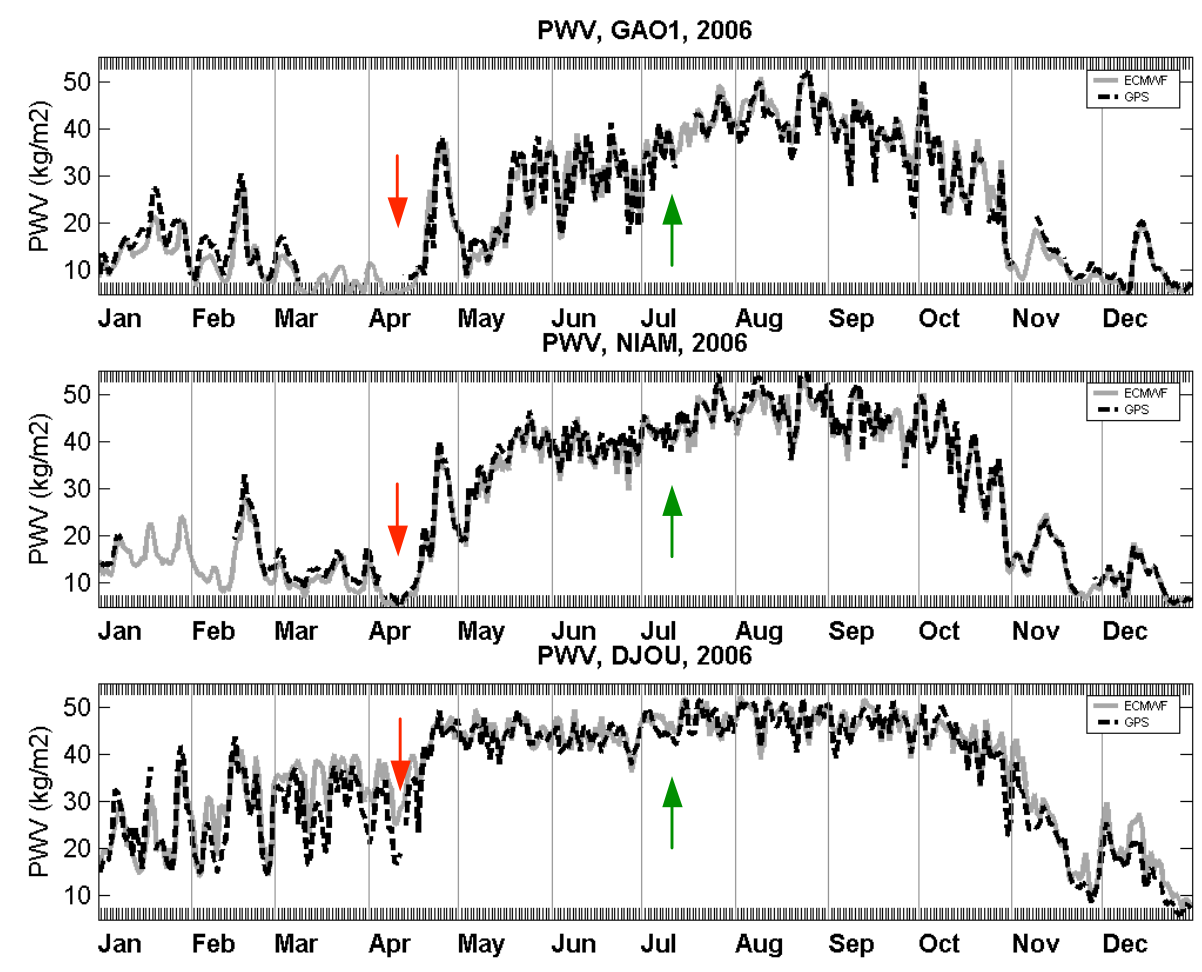

Fig. 10. Integrated atmospheric water vapour content estimated from GPS observations and analysed from ECMWF operational model at (top) Gao $\left(16.3^{\circ} \mathrm{N}-0^{\circ} \mathrm{E}\right.$; Mali), (middle) Niamey $\left(13.5^{\circ} \mathrm{N}-2.2^{\circ} \mathrm{E}\right.$, Niger) and (bottom) Djougou $\left(9.7^{\circ} \mathrm{N}-1.7^{\circ} \mathrm{E}\right.$; Benin) in 2006 (see their location in Fig. 1). Red arrows indicate the onset of the first rainy season along the Guinean Coast and green arrows the onset of the summer rainy season over the Sahel.

the deepening of a cyclonic circulation in the whole troposphere centred over the north-western part of Africa leading to abnormal south-westerly winds from the Guinean Coast to the eastern Mediterranean coast and inland moisture advection increase (not shown). From mid-May to the end of June the atmospheric moisture content was rather invariant. It increased again at the end of June consistent with the dynamical monsoon onset at this time. This increase is very clear in the Sahel (Niamey and Gao) (Fig. 10). At these latitudes the monsoon onset is associated with a northward displacement of the humidity isolines, consistent with the water vapour content increasing locally. It is less clear in the south at Djougou where the water vapour content does not vary so much. We can notice here that while the depth of the layer of westerly winds increased after the monsoon onset along the Guinean Coast (Fig. 9), the vertically integrated moisture amount stays rather constant.

The daily location of the ITD was monitored on a daily basis by the forecasters at the African Centre of Meteorological Applications for Development (ACMAD) during the summer of 2006. Their analysis was drawn subjectively based on the confluence line at the surface between southerly (monsoon humid air) and northerly (dry Harmattan) trade winds, along with associated strong contrasts in dew point temperature or relative humidity for central and eastern regions, and pressure minima at a given longitude for some regions (West coast region, also Chad, Soudan). The northward progression of the ITD (Fig. 11) is consistent with the GPS evolution during this period. The rapid northward displacement of the ITD (black lines) from $18^{\circ} \mathrm{N}$ to $22^{\circ} \mathrm{N}$ is very clear from the end of June and during the whole of July. An important feature for the monsoon and ITD progression is the Saharan heat low. Figure 12 shows the evolution of the Saharan heat low activity seen through the longitudinal and latitudinal location of the near-surface temperature maxima and the mean sea level pressure values in the centre. Around the time of the monsoon onset (from 20 June to 10 July approximately) the air temperatures were higher than $37^{\circ} \mathrm{C}$. During this period the maxima moved northwestward while the mean pressure in the centre decreased from $1011 \mathrm{hPa}$ to $1008 \mathrm{hPa}$. This evolution is consistent with the diagnostic analyses of the "canonical" monsoon onset scenario performed both with observations (Sultan and Janicot, 2003) and with regional model simulations (Ramel et al., 2006). It is also consistent with the real-time monitoring performed by the forecasters at ACMAD during summer 2006 (not shown). After the monsoon onset, the heat low centre continued to move westward until around 20 July while retreating temporary southward. Then it moved northward again until the beginning of August when the mean pressure in the centre reached its minimum value 


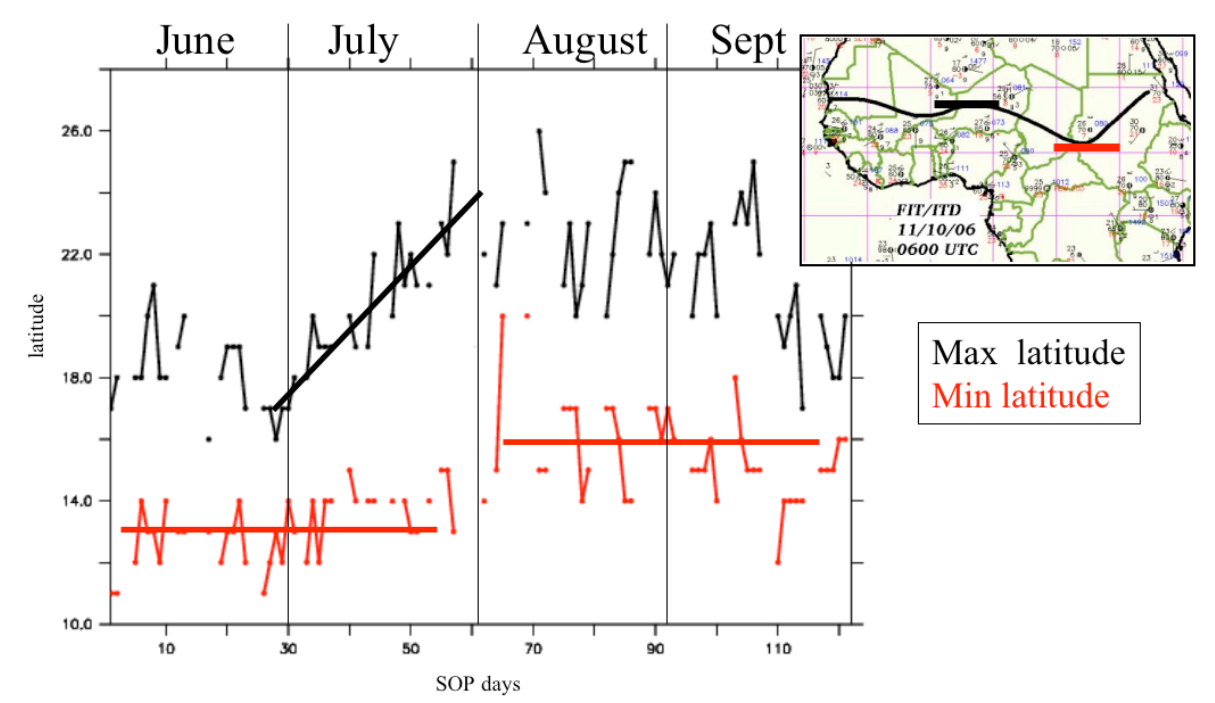

Fig. 11. Based on the daily monitoring of the ITD latitude at ACMAD in June-September 2006 (see the inset plot for one-day example and full reference at http://www.acmad.ne/en/prevision/quotidien/pmfit.htm). The black lines are for the northernmost latitude over the longitudes $15^{\circ} \mathrm{W}-30^{\circ} \mathrm{E}$ and the red lines the southernmost latitude. The $\mathrm{x}$-axis labels are expressed in days from 1 June.

of $1006 \mathrm{hPa}$. After this the heat low filled-in and retreated southeastward until the end of the monsoon season, except for a temporary westward excursion at the end of August.

\subsection{Sea surface temperatures}

Okomura and Xie (2004) among others have shown the significant role of the Atlantic equatorial cold tongue in the African monsoon annual cycle. The focus of the AMMA field campaign was on the 2006 summer monsoon but it also included an enhanced monitoring of the whole 20052007 period. In particular two oceanographic campaigns per year (in spring and fall) were carried out in the Gulf of Guinea in the scientific framework of the French EGEE project (Bourles et al., 2007). The annual cycles of the African monsoon in 2005 and 2006 were very different both in terms of convective activity and of oceanic conditions. Figure 13 depicts the latitude-time cross-section of the OLR field in 2005 for comparison with 2006 (Fig. 6). The evolution of the ITCZ between these two years was very different. In 2005 the latitude of the ITCZ over West Africa was north of its climatological mean by about $2^{\circ}$ from mid-April to mid-September. The summer monsoon also occurred early in 2005, with an onset date of the 15 June approximately. Convection was fully developed over the Sahel from about 5 July. The SST conditions were also markedly different in these two years. Figure 14 (top) shows the SST pattern on 15 June 2005 and 2006. The contrast between the two years is very clear since the equatorial cold tongue is well developed in 2005 with minima of $20^{\circ} \mathrm{C}$ while the cold tongue is also distinguishable in 2006 but with warmer SST (minima at $24^{\circ} \mathrm{C}$ ). In 2005 a strong tropical Atlantic dipole developed from April with a cooler than normal cold tongue in the Gulf of Guinea by more than $2^{\circ} \mathrm{C}$ in monthly mean and warmer SST in the northern tropical Atlantic by more than $1^{\circ} \mathrm{C}$ (see http://www.emc.ncep.noaa.gov/research/cmb/ sst_analysis/images/archive/). In 2006 moderately positive SST anomalies were present in June in the Gulf of Guinea (around $1{ }^{\circ} \mathrm{C}$ in monthly average but reaching $2^{\circ} \mathrm{C}$ in some weeks) but no significant SST anomalies were present in the following months. Differences in the timing of the SST cooling in the Gulf of Guinea between 2005 and 2006 are highlighted in the meridional profiles of SST between March and August (Fig. 14 bottom). For instance there is a quasisuperposition of the SST profiles for May 2005 and June 2006 as well as for June 2005 and July 2006 showing an approximate one-month lag of this cooling in 2006 relative to 2005. While the profiles are similar in March for the two years, the differences between the two profiles increased progressively from April to June, and decreased in July and August. This contrasting evolution of the SST fields in the Gulf of Guinea could be linked to the delay in the monsoon development in 2006 compared to 2005 (between 10 and 15 days) and this could involve some ocean-atmosphere interactions: the enhanced meridional temperature contrast in 2005 would accelerate the monsoon onset as well as the stronger monsoon winds would contribute to accelerate the cooling in the Gulf of Guinea. Several papers (Lamb, 1978a, b; Fontaine and Janicot, 1996, among others) showed that such an SST anomaly pattern is favourable to a more northward location of the ITCZ over West Africa.

\subsection{Intraseasonal variability and monsoon onset}

Matthews (2004), and Mounier and Janicot (2007) outlined the impact of intraseasonal variability on the West African 

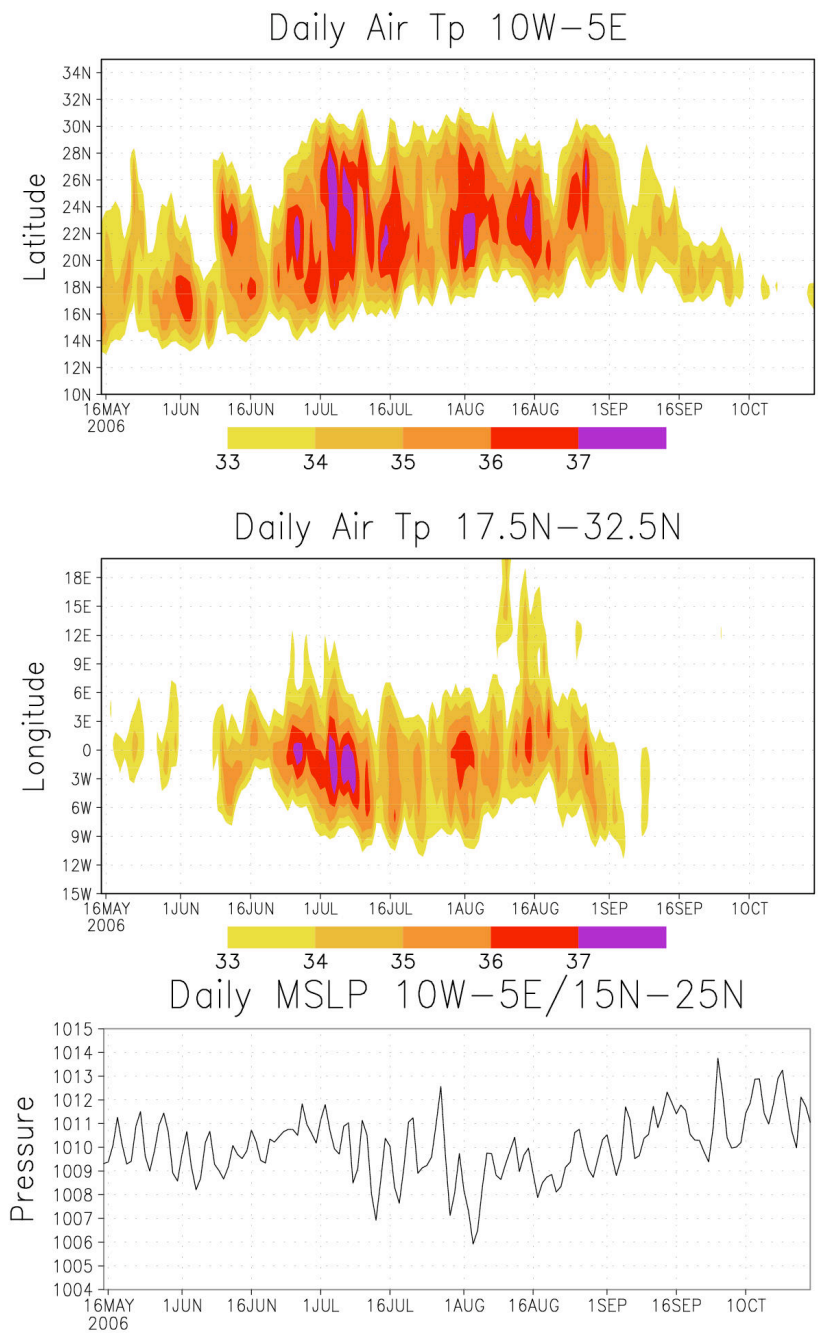

Fig. 12. Top: Time-latitude diagram of NCEP daily temperature $\left({ }^{\circ} \mathrm{C}\right)$ at the sigma level 0.995 averaged over the longitudes $10^{\circ} \mathrm{W}-$ $5^{\circ} \mathrm{E}$. Middle: Time-longitude diagram of NCEP daily temperature $\left({ }^{\circ} \mathrm{C}\right)$ at the sigma level 0.995 averaged over the latitudes $17.5^{\circ} \mathrm{N}-$ $32.5^{\circ} \mathrm{N}$. Bottom: Time series of NCEP daily mean sea level pressure $(\mathrm{hPa}-1000)$ at the sigma level 0.995 averaged over the domain $15^{\circ} \mathrm{N}-25^{\circ} \mathrm{N} / 10^{\circ} \mathrm{W}-5^{\circ} \mathrm{E}$.

monsoon, and especially at the 40-day timescale linked to MJO (Madden-Julian Oscillation) activity in the Indian and West Pacific sectors. Such an MJO event occurred in 2006 during the monsoon onset and could have contributed to its delay. Figure 15 depicts the combined OLR fields (shaded) and $200 \mathrm{hPa}$ NCEP velocity potential anomaly fields on the 25 June, 1, 10 and 19 July 2006. On 25 June convective activity is enhanced over the Indian and the West Pacific sectors with a pattern that resembles those associated with MJO events. It is characterised by a wave-number one anomaly pattern in the velocity potential with upper-level large-scale divergence in this sector and convergence over the central and eastern Pacific. By the 1 July the convective activity was

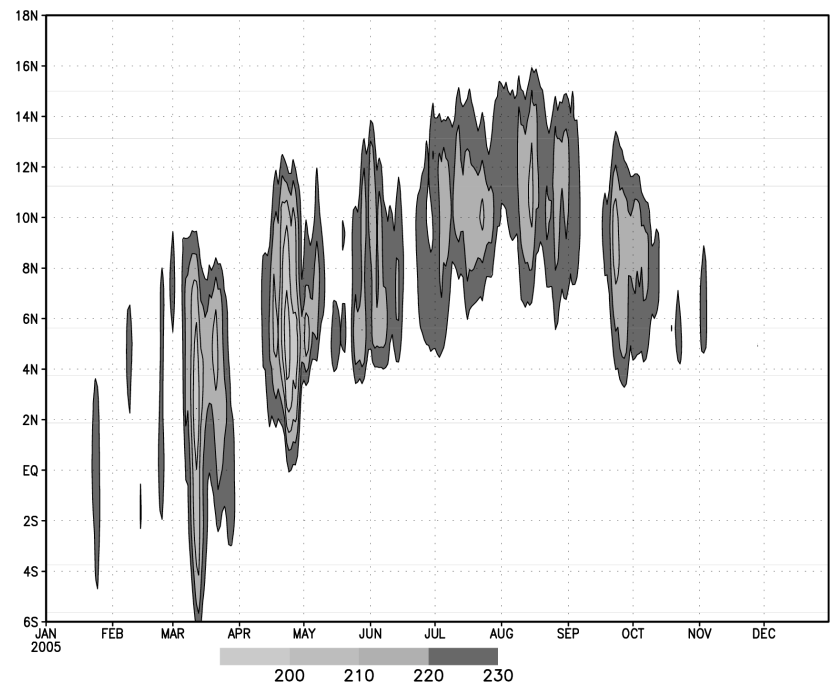

Fig. 13. Same as Fig. 6 but for 2005 .

maintained and the wave pattern had moved eastward (possibly linked to equatorial Kelvin wave dynamics, see Fig. 17). Also, the subsidence area had moved from Central America to Africa preventing the development of convective activity in this domain. By the 10 July the MJO structure had disaggregated over the Indian and West Pacific sectors and the velocity potential wave pattern had weakened. In particular the subsiding area over Africa had disappeared removing the large-scale suppression of convection over Africa where the low-levels fields were favourable for the monsoon development. Finally 20 July corresponded to the first peak of the African monsoon activity (see Figs. 6 and 8). Figure 16 displays the time-longitude diagram of $300 \mathrm{hPa}$ temperature anomalies averaged between $10^{\circ} \mathrm{S}$ and $20^{\circ} \mathrm{N}$ and for shown between 1 June and 31 July 2006. A warm anomaly consistent with large-scale subsidence was initiated over the Indian sector around the 20 June and propagated both eastward and westward towards the Africa - tropical Atlantic domain which is reached at the end of June. This signal was present for about 20 days and disaggregated around mid-July in connection with the disappearance of the MJO forcing in the Indian sector. This signal is very similar to the one highlighted by Matthews (2004) in his composite analysis of 40-day convection variability over Africa linked to MJO-type convective activity.

Figure 17 depicts a similar time-longitude diagram but computed on the $200 \mathrm{hPa}$ velocity potential anomaly field averaged for the latitudinal range $5^{\circ} \mathrm{S}-15^{\circ} \mathrm{N}$ from March to November 2006. A regular eastward propagation of positive and negative anomalies is very clear with a mean periodicity of about 40-50 days, consistent with the expected upperlevel equatorial-wave dynamics associated with MJO activity. These dynamical structures were only weakly coherent during March-April but they were enhanced between May 


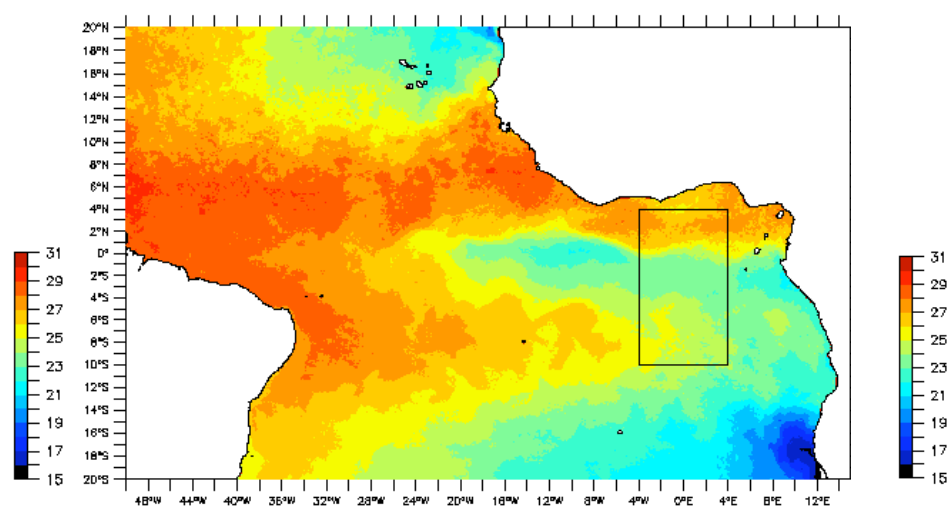

$\operatorname{Tim} 15$, ances

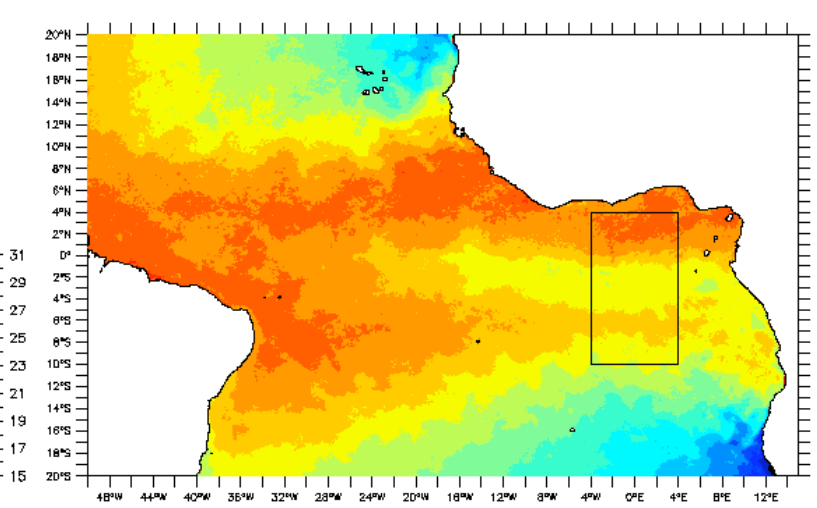

inme 16. 3000

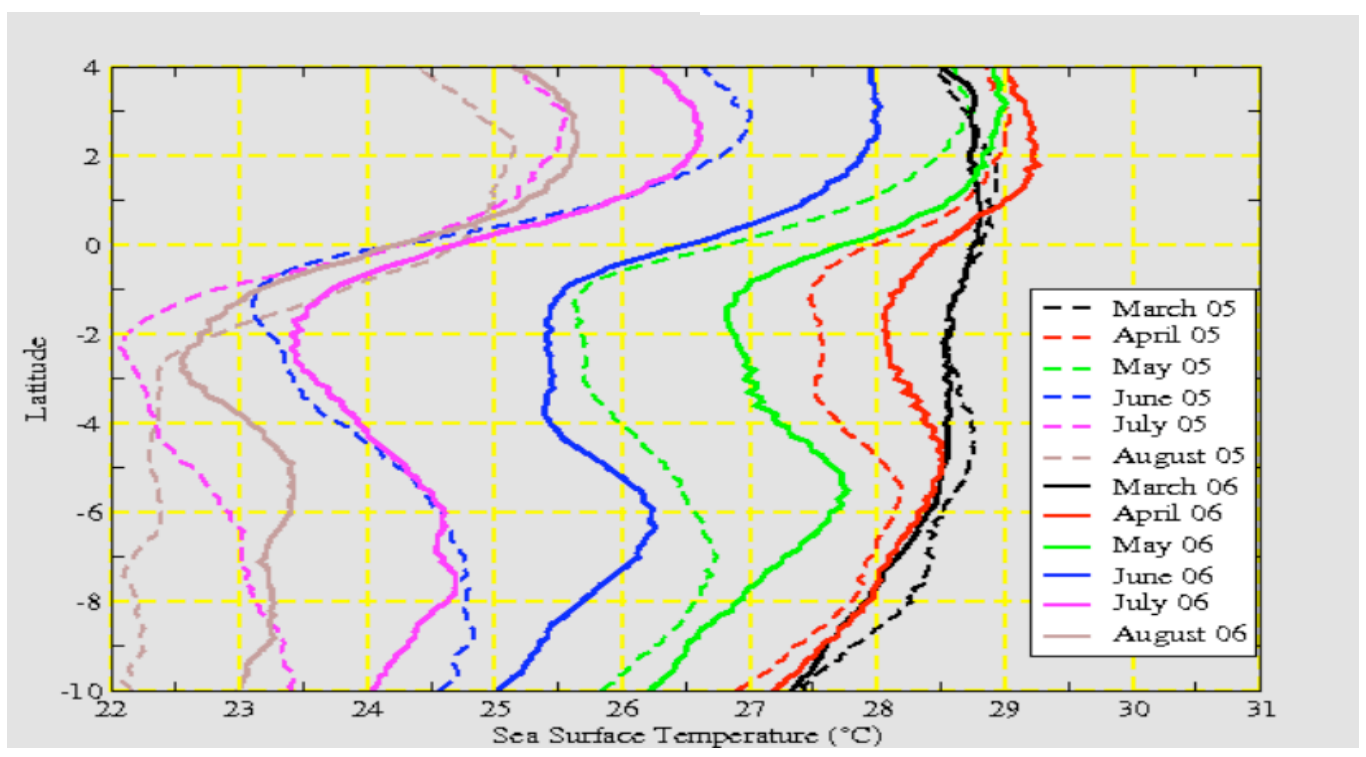

Fig. 14. Upper left: SST from OSISAF (http://www.osi-saf.org/index.php) on 15 June 2005. Upper right: SST from OSISAF on 15 June 2006. Bottom: Meridional cross-section of monthly SST from OSISAF averaged between $4^{\circ} \mathrm{W}-4^{\circ} \mathrm{E}$ from March to August in 2005 and 2006. The domain where these data have been taken is indicated in the upper figures.

and September when they probably contributed to the modulation of convective activity in West and Central Africa. In particular, as seen on Fig. 15, positive anomalies consistent with large-scale subsidence crossed the African sector at the time of the monsoon onset at the end of June.

Intraseasonal variability of convection over West and Central Africa during summer has also been investigated at the 10-25-day time scale by Sultan et al. (2003), Mounier and Janicot (2004), Mounier et al. (2008). An EOF analysis showed evidence of two independent modes of convection, dominant in the 10-25-day periodicity domain. The first mode is characterized by a stationary and uniform modulation of convection within the African ITCZ, associated with a modulation of the zonal low-level wind over the equatorial Atlantic and a zonal dipole of convection between Africa and the north equatorial Atlantic off the coast of South Amer- ica. The second mode highlights convective activity modulation over the Sahel within a westward propagating signal from eastern Africa to the western tropical Atlantic. Figure 22 shows the intraseasonal variability of convection for the summer of 2006, using filtered OLR data in the 10-25day periodicity over the Guinean coast (white dot curve) and over the Sahel domain (black dot curve), and in the 25-90-day periodicity over the Whole West Africa (no dot curve). Positive/negative OLR values indicate weaker/higher convective phase. The time series of the 25-90-day modulation of convection is consistent with the $200 \mathrm{hPa}$ velocity potential time sequence of Fig. 17 showing enhanced convection during the crossing of negative velocity potential anomaly signal and vice-versa. In particular the weaker convective phases during the monsoon onset centered on 1 July and around mid-August are well-marked and alternate 

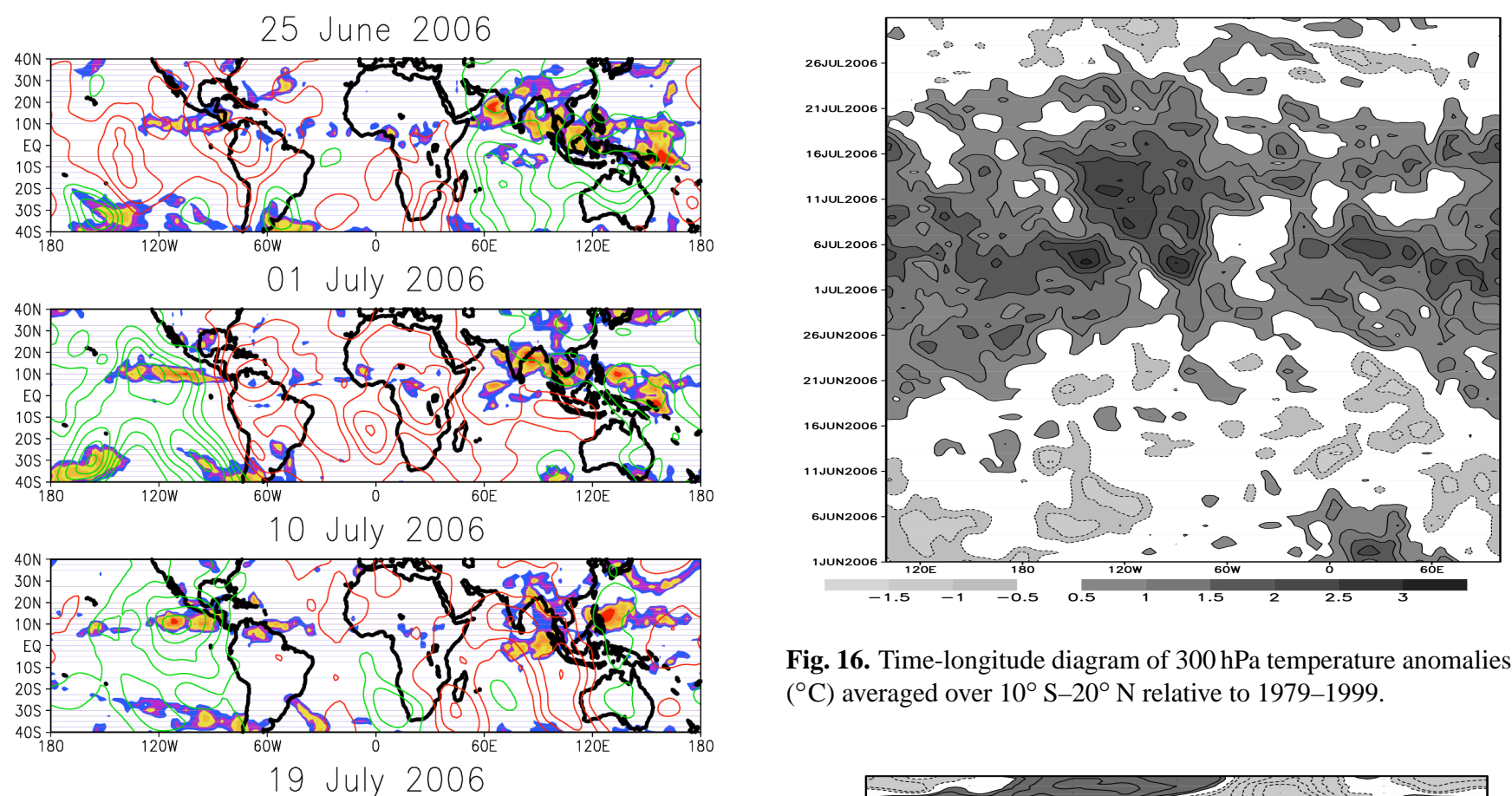

Fig. 16. Time-longitude diagram of $300 \mathrm{hPa}$ temperature anomalies $\left({ }^{\circ} \mathrm{C}\right)$ averaged over $10^{\circ} \mathrm{S}-20^{\circ} \mathrm{N}$ relative to $1979-1999$.

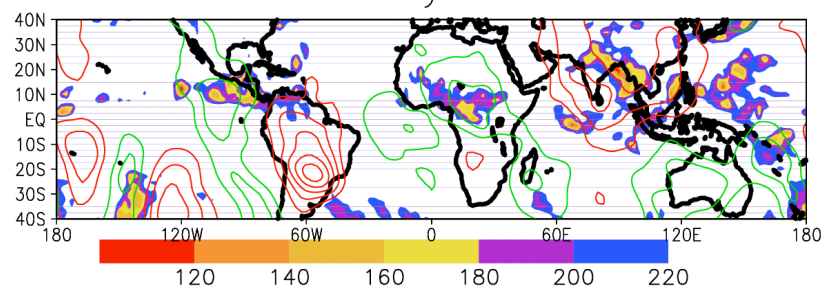

Fig. 15. Daily OLR values (shaded) and $200 \mathrm{hPa}$ NCEP velocity potential anomalies (relative the period 1979-1999) on 25 June, 1 July, 10 and 19 July 2006. Green (red) contours means upper-level large-scale divergence (convergence), by step of $2 \times 10^{6} \mathrm{~m}^{2} \mathrm{~s}^{-2}$ (the zero isolines are not displayed).

with enhanced convective phases centered on 1 August and around 5 September as seen in Fig. 6. On the other hand 1025-day periodicity modulation of the convection is also highlighted in Fig. 22 with amplitudes higher than $10 \mathrm{~W} \mathrm{~m}^{-2}$, and with uncorrelated fluctuations between the Sahel (black dots) and the Guinean coast (white dots) latitudes. They are consistent with the two main modes identified by the EOF analysis performed in the previous papers. All these three curves help to interpret the OLR fluctuations seen in Fig. 6 in the northern summer and will be useful for future investigations.

\section{Synoptic variability}

\subsection{African easterly waves}

The AEJ supports the development of African easterly waves (AEW), which represent the main synoptic-scale weather systems in the African monsoon and downstream tropical At-

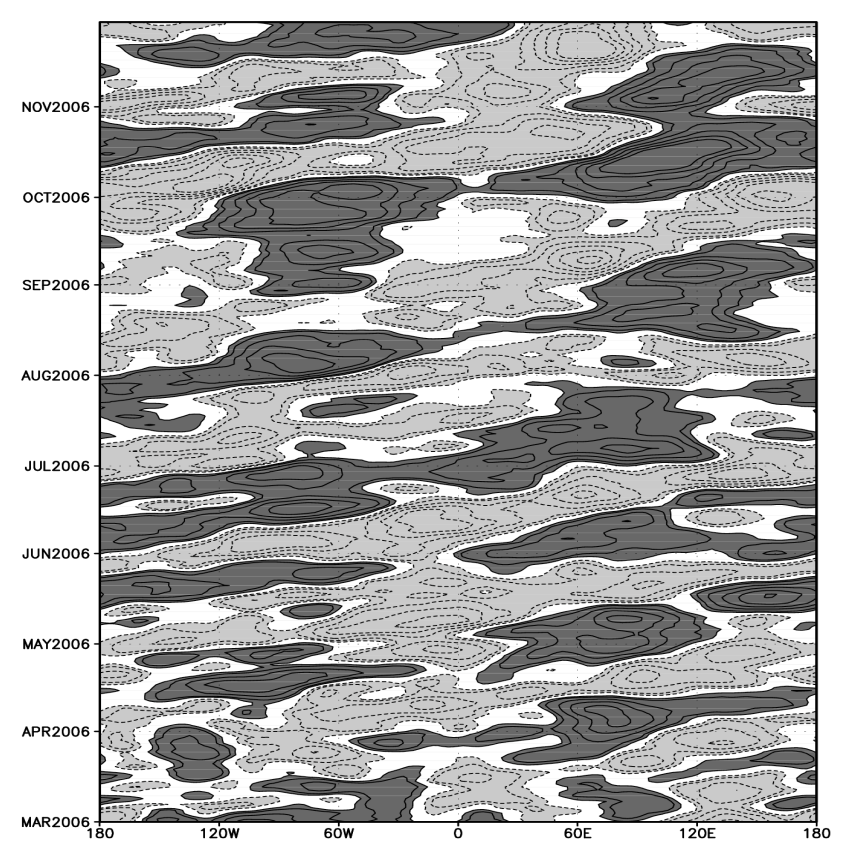

Fig. 17. Time-longitude diagram of $200 \mathrm{hPa}$ velocity potential anomalies averaged on $5^{\circ} \mathrm{S}-15^{\circ} \mathrm{N}$ relative to $1979-1999$. Positive (negative) values are in black (grey) with isolines 1, 2, 4, 6, 8 and $10 \times 10^{6} \mathrm{~m}^{2} \mathrm{~s}^{-2}$.

lantic during northern summer. AEWs are important systems because of their association with daily rainfall over tropical Africa (Reed et al., 1977) and because they can serve as precursors for tropical cyclones (Avila and Pasch, 1992). Despite their importance there are still fundamental gaps in our understanding of the dynamics and evolution of these waves as they move across Africa and the Atlantic including how 

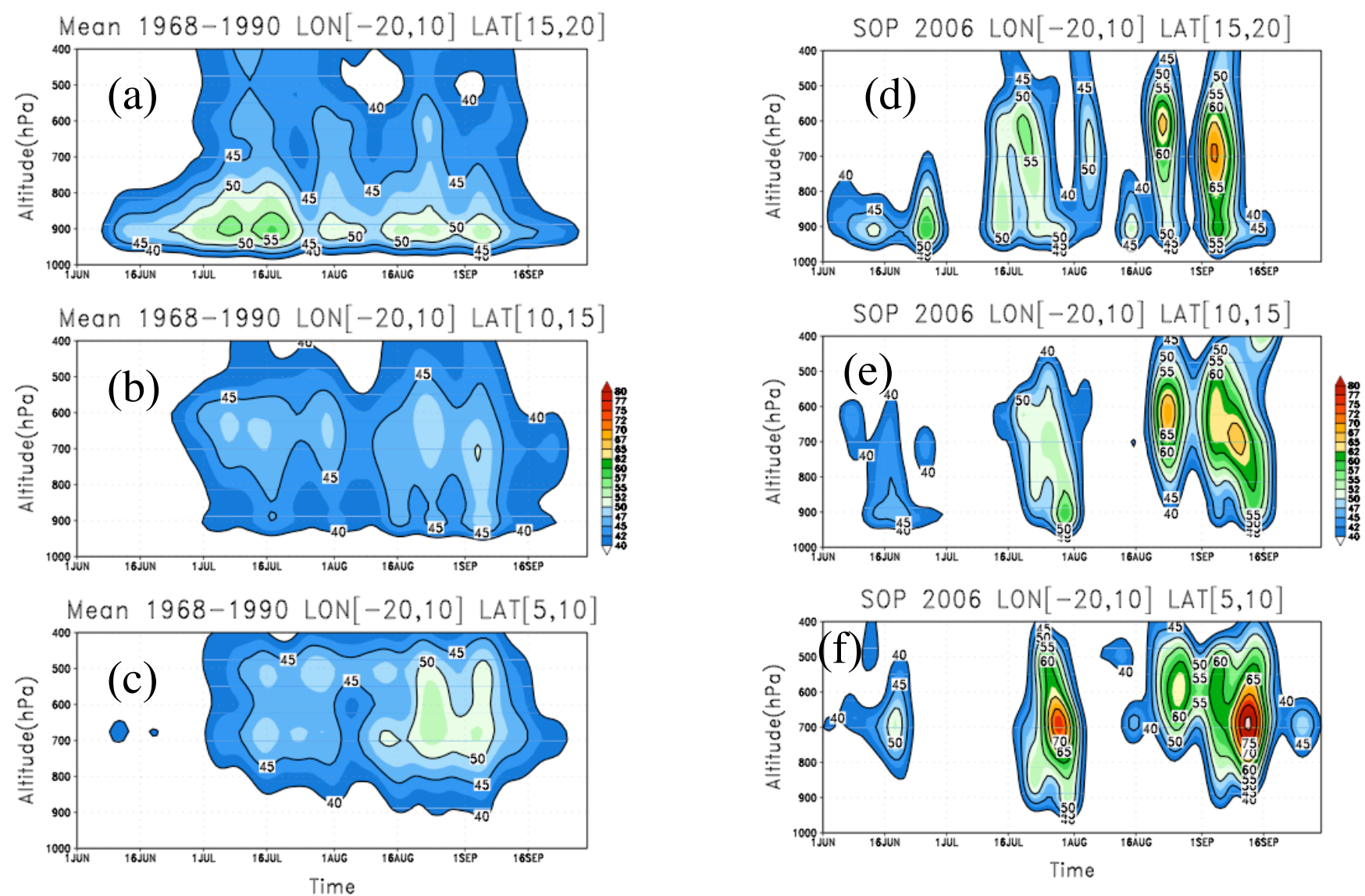

Fig. 18. Vertical and spatial distribution of the mean AEW activity, using wavelet analysis of the daily meridional wind, over the West Africa and near Tropical Atlantic in 3 domains; longitudes $20^{\circ} \mathrm{W}-10^{\circ} \mathrm{E}$, latitudes $15^{\circ} \mathrm{N}-20^{\circ} \mathrm{N}, 10^{\circ} \mathrm{N}-15^{\circ} \mathrm{N}$ and $5^{\circ} \mathrm{N}-10^{\circ} \mathrm{N}$. Left panels $(\mathbf{a}$, b, c) show the 1968-1990 climatology, right panels (d, e, f) the AMMA summer SOP.

they interact with convection and MCS. This is a key-issue in the AMMA project.

Figures 18 and 19 provide a brief overview of the AEW activity during summer 2006 over Africa. Following Lavaysse et al. (2006), an index of the AEW activity has been computed using daily NCEP reanalysis. This index uses the wavelet analysis, with the Morlet mother Wavelet (Torrence and Compo, 1998) of the meridional wind component. The daily 3-5 days spectral density has been summed in each grid point and each pressure level independently. Figure 18 shows this AEW activity index averaged over West Africa and the near Tropical Atlantic (longitudes $20^{\circ} \mathrm{W}-10^{\circ} \mathrm{E}$ ) in three domains (latitudes $15^{\circ} \mathrm{N}-20^{\circ} \mathrm{N}, 10^{\circ} \mathrm{N}-15^{\circ} \mathrm{N}$ and $5^{\circ} \mathrm{N}-10^{\circ} \mathrm{N}$ ). The $1968-1990$ June to October climatology is also displayed (Fig. 18a, b, c) to compare with the AEW activity during the AMMA summer SOP (Fig. 18d, e, f). The AEWs propagate along two axes, on each side of the AEJ. In the southern part (around $5^{\circ} \mathrm{N}-10^{\circ} \mathrm{N}$; Fig. 18c), the waves are close to the jet and are associated with convection. In the 1968-1990 climatology, these waves occur from June to September with a maximum mainly during the second part of the monsoon season. The altitudes of these waves are near to the jet levels (between 700 to $600 \mathrm{hPa}$ ). During the AMMA summer SOP (Fig. 18f) three periods of intense wave activity are detected, the longest being in the second part of the monsoon season between mid-August and mid-September. The strongest wave activity occurs around the 10 September. In the northern part of the AEJ $\left(15^{\circ} \mathrm{N}-20^{\circ} \mathrm{N}\right.$; Fig. 18a), the altitude of the waves detection is lower than in the southern part, between $925 \mathrm{hPa}$ and $850 \mathrm{hPa}$ (Diedhiou et al., 1999; Thorncroft and Hodges, 2000). In the climatology, their activity is highest in July but present throughout the monsoon season. During the SOP, low-level waves are detected early in the season, in June (Fig. 18d). Later, the altitude of the waves becomes very close to that of the AEWs in the southern domain. We find again high activity in mid-July and between mid-August and mid-September at the AEJ level. The domain defined between $10^{\circ} \mathrm{N}$ to $15^{\circ} \mathrm{N}$ illustrates the transition from the northern regime in June to the southern regime in August and September. It shows that the Sahel is affected by simultaneously the southern and northern axes of the AEW. 
Berry et al. (2007) have recently proposed an objective method for tracking individual AEWs. AEW-troughs are diagnosed based on advection of curvature vorticity by the rotational flow. This diagnostic helps distinguishing the synoptic scale trough from embedded mesoscale features that often contaminate the analysis. Figure 19 presents a Hovmoeller diagram of the $700 \mathrm{hPa}$ curvature vorticity averaged between $5^{\circ} \mathrm{N}-15^{\circ} \mathrm{N}$, and based on the operational NCEP analysis. A sequence of vorticity tracks can be seen on the diagram moving from east to west. The numbers mark the initial locations of objectively analysed AEW-troughs, with red numbers denoting AEWs that were later associated with named tropical cyclones in the tropical Atlantic. During the July-September period, a total of 27 AEWs were objectively analysed (compared with 31 in 2004 and 28 in 2005). July was very different from the later months with six out of seven of the first waves forming close to the longitude of Niamey or west of it. In August the AEWs were initiated further east, between $10^{\circ} \mathrm{E}-20^{\circ} \mathrm{E}$, but AEWs over Niamey were still weak. Starting at the end of August and going into September the AEWs became more coherent (consistent with Fig. 18), with stronger amplitudes over most of tropical North Africa. Interestingly, several AEWs also appeared to start further east, between $20^{\circ} \mathrm{E}-30^{\circ} \mathrm{E}$ at this time. It should also be noted that all seven of the AEWs that became named tropical cyclones were initiated east of Niamey and six of these occurred after the middle of August.

\subsection{Kelvin waves}

In addition to the well-known synoptic scale AEWs, Mounier et al. (2007) have shown the existence of another synopticscale weather system over the Atlantic and Africa during northern summer, the convectively coupled Kelvin waves. Propagating eastward, many waves originate from the Pacific sector, interact with deep convection of the marine ITCZ over the Atlantic and the continental ITCZ over West and Central Africa, then weaken over East Africa and the Indian Ocean. These waves modulate the life cycle and track of individual westward propagating convective systems. They typically have a wavelength of $8000 \mathrm{~km}$, a phase speed of $15 \mathrm{~m} \mathrm{~s}^{-1}$, resulting in a periodicity centred on 6-7 days. When such a wave is present over Africa its mean impact on rainfall and convection is of the same level as for the African easterly waves (not sure what you mean). Mekkonen et al. (2008) also highlighted the presence and impact of Kelvin waves over eastern Africa where their periodicity reduces to about 4 days.

Figure 20 shows a time-longitude diagram of daily OLR anomalies based on 1979-2001 and averaged over 7.5 S$7.5^{\circ} \mathrm{N}$ (shaded), and filtering of OLR (green ellipses for equatorial Kelvin wave, black ellipses for equatorial Rossby wave, blue ellipses for MJO signal) from May to October 2006. The blue arrows delineate three Kelvin wave occurrences crossing Africa in June. The impact of such waves

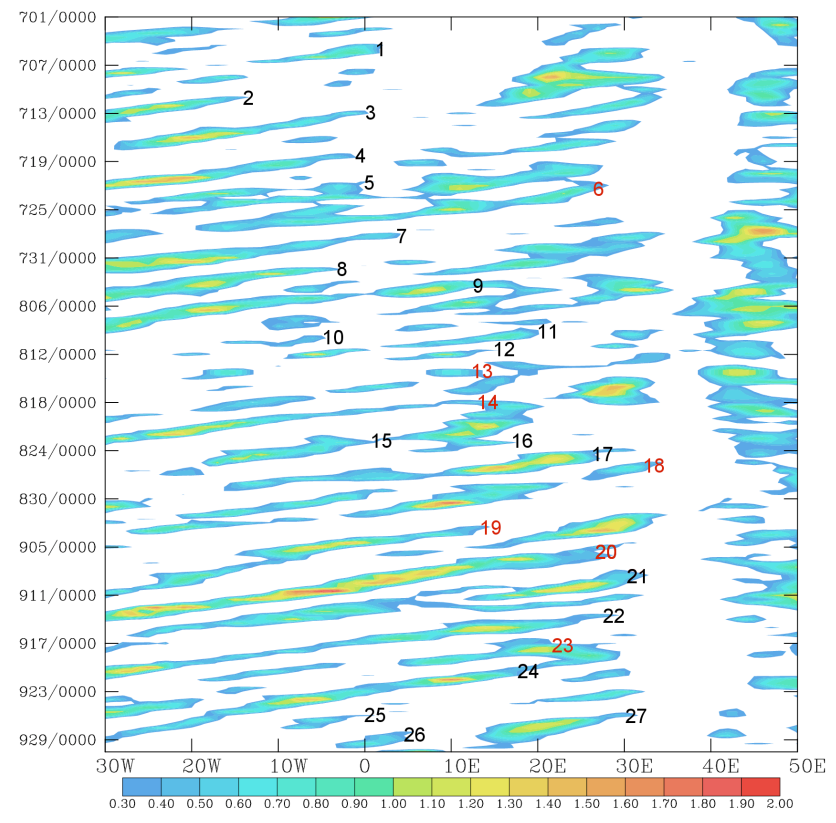

Fig. 19. Hovmoeller space-time diagram of $700 \mathrm{hPa}$ curvature vorticity averaged between $5^{\circ} \mathrm{N}$ and $15^{\circ} \mathrm{N}$ based on NCEP analysis. The numbers refer to synoptic systems that meet the tracking criterion used by Berry et al. (2007). Those in red became tropical cyclones in the Atlantic basin. These were Chris (6), Ernesto (13), Debby (14), Florence (18), Gordon (19), Helene (20), Isaac (23). On the vertical axis time is expressed as month-day/hour.

on convective activity over West Africa is shown in the right panel. The modulation of rainfall amount through the GPCP (Global precipitation Climatology Project; Adler et al., 2003) rainfall estimate is shown on a time-latitude diagram. In June the ITCZ was still along the Guinean Coast since the summer monsoon onset had not occurred yet. Three peaks of high precipitation were detected between 1 and 18 June, corresponding to the crossing of the Kelvin waves. Mounier et al. (2007) have shown that the impact of Kelvin waves has a seasonal evolution and that it is stronger when the ITCZ is closer to the equator since the interactions between convection and these equatorially-trapped waves are facilitated. This is the case during the first rainy season over the Guinean Coast in 2006.

\subsection{Dry intrusions}

Another important issue in the AMMA project is the study of extra-tropical dry air intrusions. A product was setup during the SOP and dedicated to the monitoring and forecasting of such intrusions in the West African mid-troposphere. These dry intrusions correspond to extra-tropical plumes of dry air originating from the polar jet that subsequently subside slowly down to the mid level of the troposphere towards the equatorial region (Roca et al., 2005a). Over the Sahel, these dry filamentary structures interact with deep convection 


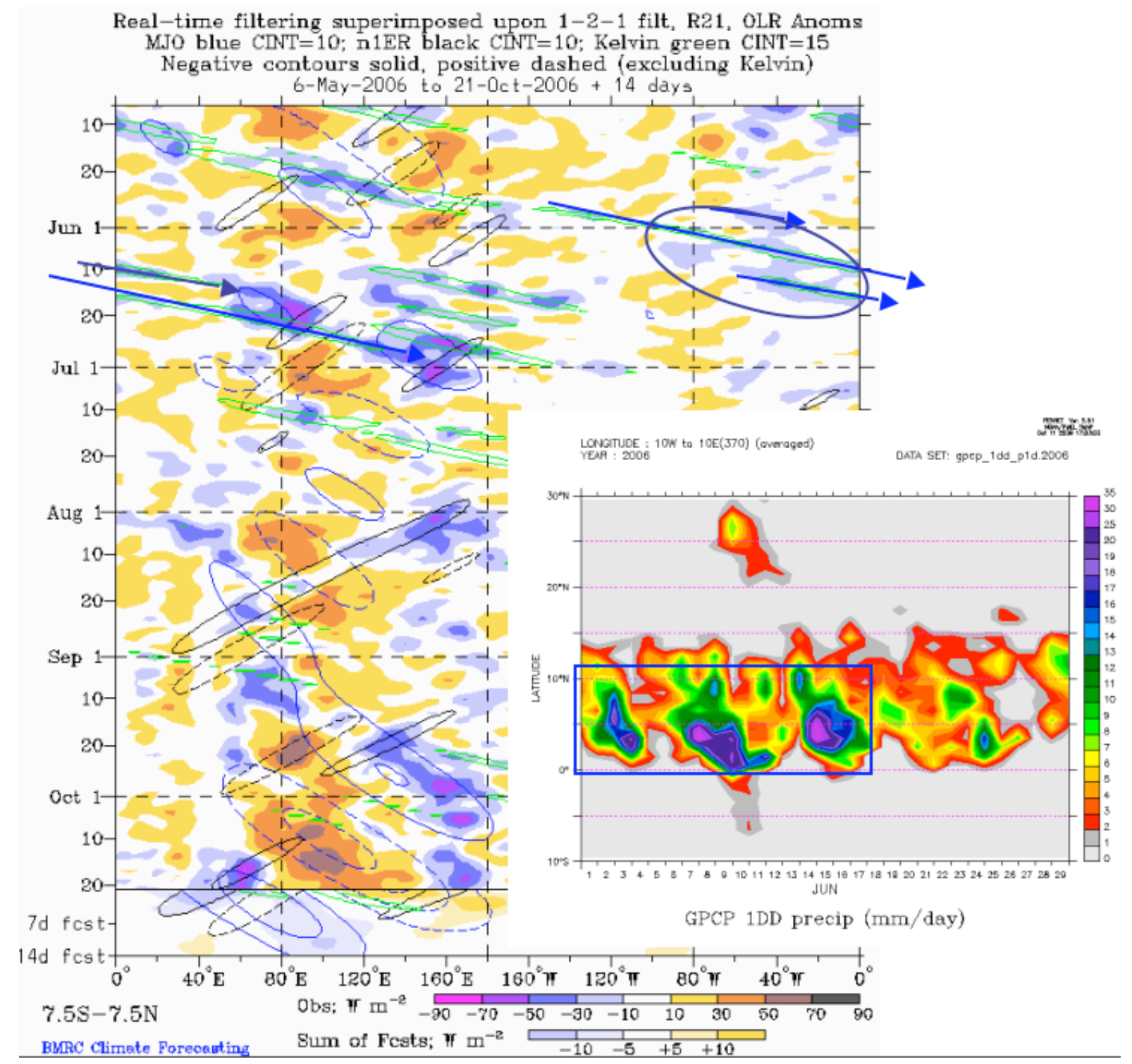

Fig. 20. Time-longitude diagram of OLR anomalies based on 1979-2001 and averaged over longitudes $7.5^{\circ} \mathrm{S}-7.5^{\circ} \mathrm{N}$ (shaded), and real-time filtering of OLR (green ellipses for equatorial Kelvin wave, black ellipses for equatorial Rossby wave, blue ellipses for MJO signal) from May to October 2006 (http://www.bom.gov.au/bmrc/clfor/cfstaff/matw/maproom/OLR_modes/index.htm; courtesy of M. Wheeler). Blue arrows delineate the Kelvin wave occurrences in June crossing Africa. The panel on the right depicts the time-latitude diagram of GPCP daily rainfall estimate averaged on $10^{\circ} \mathrm{W}-10^{\circ} \mathrm{E}$ in June 2006 . The blue big ellipse on the time-longitude diagram highlights the train of three Kelvin waves crossing Africa in June and their rainfall impact is highlighted by the blue rectangle on the time-latitude diagram.

in a complex manner: inhibiting its development like over the tropical ocean (e.g. Redelsperger et al., 2002) and/or favouring the organisation of already triggered convection in the form of squall lines and fast moving long lived MCS (Roca et al., 2005a). As a consequence these dry intrusions are thought to contribute to the intraseasonal/synoptic variability of precipitation in the region. To address these issues, a Lagrangian advection-condensation model (Pierrehumbert and Roca, 1998) was used to compute the relative humidity and to keep track of the origin of air masses. The model was run using temperature and winds from the NCEP operational analysis and forecasts and maps of the relative humidity at $500 \mathrm{hPa}$ as well as the latitude of the last saturation of the air masses were produced every $6 \mathrm{~h}$ at 0.5 degrees resolution for the full summer 2006. The latitude of last saturation is a key Lagrangian parameter. It is derived from the trajectory analysis. The trajectories are computed back in time up to 12.5 days. The saturation history of the air mass is stored for each trajectory. It corresponds to the time and location of the coolest temperature along the trajectory during the retro 


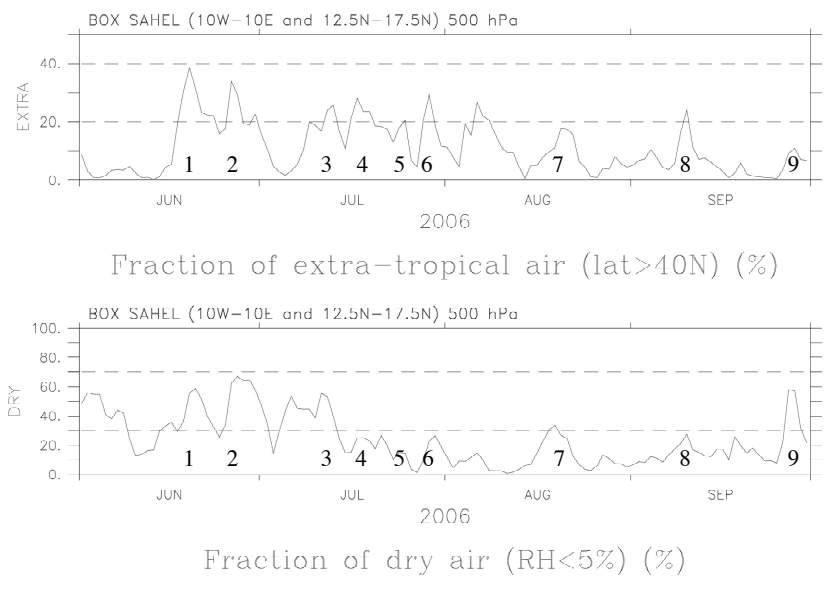

Fig. 21. Top: Time series of the fraction of extra-tropical air over the $10^{\circ} \mathrm{W}-10^{\circ} \mathrm{E} 12.5^{\circ} \mathrm{N}-17.5^{\circ} \mathrm{N}$ Sahelian box at $500 \mathrm{hPa}$. Bottom: Time series of the fraction of dry air $(\mathrm{RH}<5 \%)$ at $500 \mathrm{hPa}$ over the same box. See text for details.

flight or, if applicable, to the location at which the trajectory was stopped due to deep convection. From this information, the last saturation time and location is readily computed. Two indices are derived from these integrations. The areal fraction of dry air defined as relative humidity below $5 \%$ over a Sahelian box and the fraction of the trajectories that originate from a latitude greater than $40^{\circ} \mathrm{N}$ (Roca et al., 2005a) to support documentation of the extra-tropical dry intrusion intraseasonal variability. Figure 21 shows the time series of these indices for the summer 2006.

Nine dry intrusion events have been identified from the combined objective analysis of the individual maps and of the time series of the indices, and are reported in Fig. 21. The duration of theses dry intrusion events is from 1 to 9 days. They occur at two main temporal scales during the season: a short intra-seasonal scale (10-20 days) and an MJOlike scale (40-50 days) (Roca and Deme, 2008). The latter case corresponds rather well with the equatorial velocity potential anomalies seen in Fig. 17 and with positive 25-90day OLR anomalies in Fig. 22 (Events: 3,7 and 9 occurring, respectively, at the beginning of July, mid-August and late September) for which pan-west African dry intrusions occur. The interactions between these equatorial perturbations and the dry intrusion occurrences are currently unknown. The shorter mode (Events: 1, 2, 4, 5, 6 and 8) is sometimes contemporaneous with positive 10-25-day OLR anomalies over the Sahel (black dot curve in Fig. 22) or AEWs (Fig. 19) and thus contributes to produce a dry mid-troposphere simultaneous with some lower level dynamical forcing of deep convection. The analysis of the relative impacts of the two forcing mechanisms on the precipitation variability will be further analyzed and reported elsewhere. Compared with the last 20 years, the extra-tropical dry intrusion activity in 2006 were close to the climatology (Roca et al., 2005b) and were,

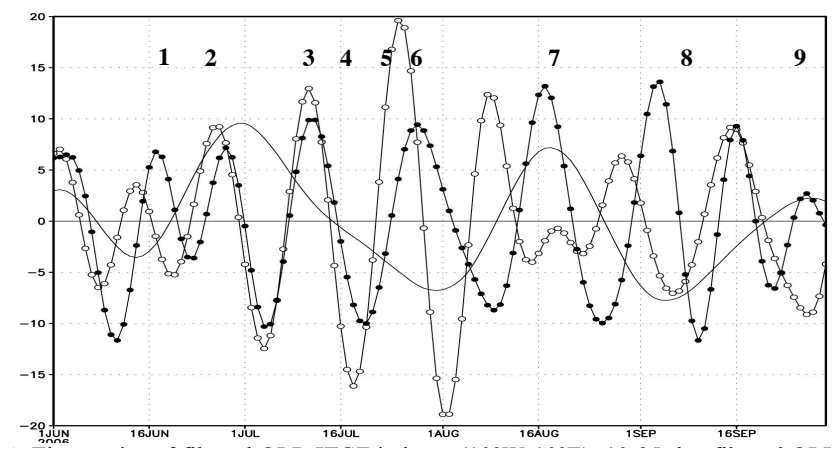

Fig. 22. Time series of filtered OLR ITCZ indexes $\left(10^{\circ} \mathrm{W}-10^{\circ} \mathrm{E}\right)$ : $10-25$-day filtered OLR values averaged over $2.5^{\circ} \mathrm{N}-10^{\circ} \mathrm{N}$ (white dot curve) and over $12.5^{\circ} \mathrm{N}-17.5^{\circ} \mathrm{N}$ (black dot curve); 25-90-day filtered OLR values averaged over $2.5^{\circ} \mathrm{N}-17.5^{\circ} \mathrm{N}$ (no dot curve). Values in $\mathrm{W} \mathrm{m}^{-2}$. Numbers 1 to 9 correspond to the dry intrusions of Fig. 21.

for instance, less frequent by about $50 \%$ than for 1992, a very active year (Roca et al., 2005a). Note that 2006 is the only year for which the two modes of variability of dry intrusions appeared so clearly. More detailed analysis of these two types of events should help to clarify the role of the midtropospheric dry air onto the precipitation variability.

\section{Land surface variability}

\subsection{Continental hydrology}

The unusual seasonal evolution of the rainfall in 2006 had a straightforward impact on the surface hydrology, especially in the Sahel, both at local scale and at regional scale, as illustrated in Fig. 23. Over most of the Sahel, no significant rain events were recorded until the second 10-day period of July. Then, rain events occurred regularly, with intensities consistently over the runoff threshold, resulting in a much larger number of rain events producing runoff than in 2005 (Fig. 23a). On the intensively monitored local catchment of Wankama $\left(2 \mathrm{~km}^{2}\right) 460 \mathrm{~mm}$ of rain was recorded in 2005 (in the lower range of the 2005 rainfall over the Niamey mesosite, shown in Fig. 1) compared with $513 \mathrm{~mm}$ in 2006 (in the middle range of the 2006 rainfall over the Niamey mesosite); the corresponding runoff, expressed in water depth, was $14.5 \mathrm{~mm}$ in 2005 (runoff coefficient $=3.2 \%$ ) and $45 \mathrm{~mm}$ in 2006 (runoff coefficient $=8.2 \%$ ).

At the regional scale, the annual average daily discharge of the Niger River at Niamey did not vary much between 2005 $\left(1006 \mathrm{~m}^{3} \mathrm{~s}^{-1}\right)$ and $2006\left(1015 \mathrm{~m}^{3} \mathrm{~s}^{-1}\right)$ but the timing of the hyetograph was markedly different, as shown in Fig. 23b. Low waters persisted much later than usual, with the first significant increase of the discharge occurring on the 10 July as a local peak resulting from the first significant local rain events in the Niamey region. This roughly means a delay of 1 


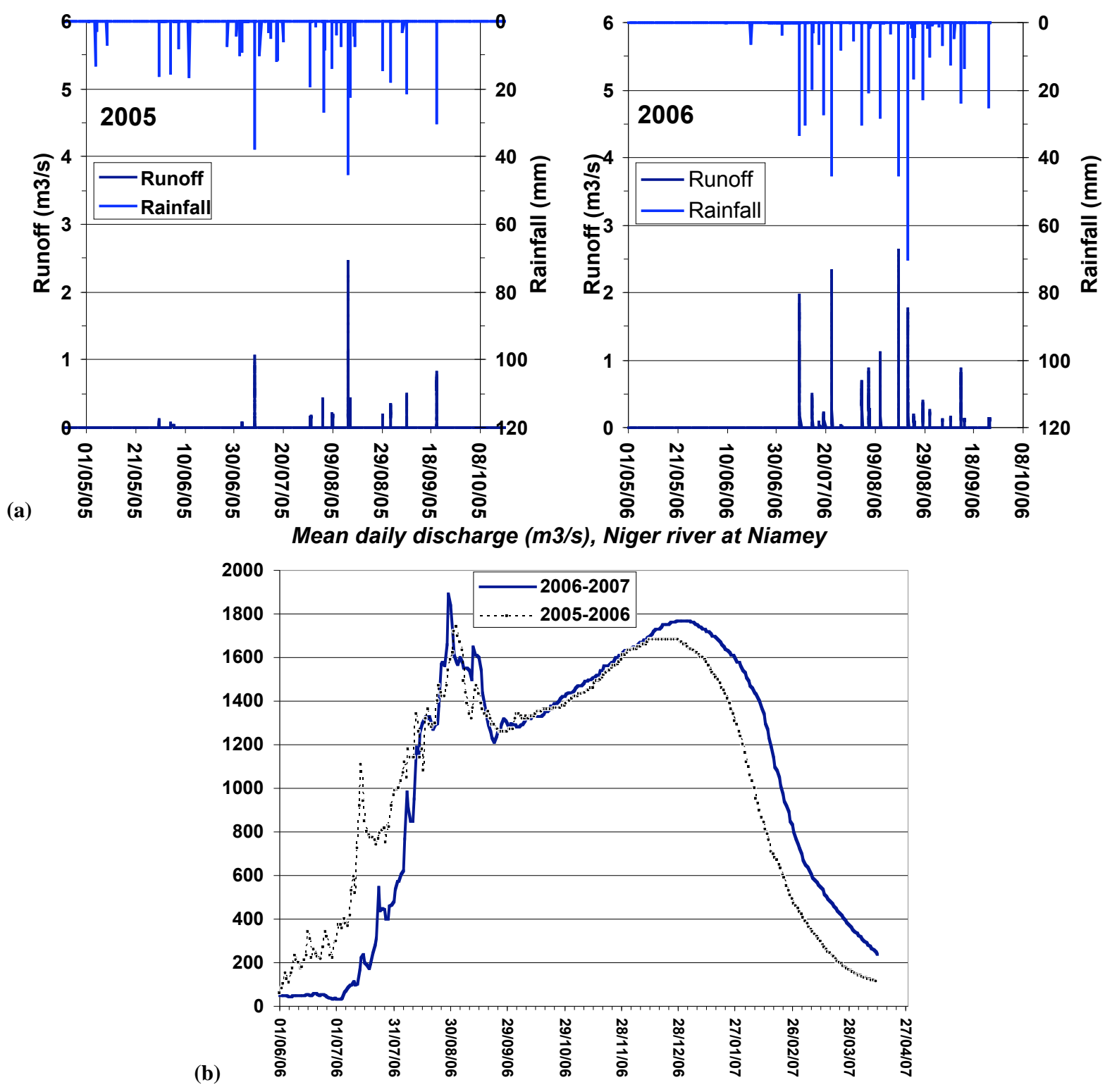

Fig. 23. Surface hydrology of the Sahel in 2006, compared to that of 2005 . (a) Local scale (Wankama catchment, $2 \mathrm{~km}^{2}$, on the Niamey Meso-site): with a similar total rainfall of around $500 \mathrm{~mm}$ for the 2 years (top-down bars), rain events of higher intensity were recorded in 2006, resulting in higher runoff (bottom-up bars). (b) Regional scale (Niger River at Niamey, $860000 \mathrm{~km}^{2}$ ): the 2006 flood started unusually late but the two flood peaks of August and December were larger in 2006 than in 2005.

month for the start of the annual flood. By mid-August however the 2006 discharge caught up with the 2005 value and the first peak flow at the end of August was larger and happened slightly earlier in 2006 than in $2005\left(1890 \mathrm{~m}^{3} \mathrm{~s}^{-1}\right.$ the 29 August against $1740 \mathrm{~m}^{3} \mathrm{~s}^{-1}$ the 3 September). The second peak flow, produced by the rain falling over Guinea and Southern Mali, was observed during the last week of December, in agreement with the average climatology; again with a larger value in $2006\left(1770 \mathrm{~m}^{3} \mathrm{~s}^{-1}\right)$ compared with 2005 $\left(1680 \mathrm{~m}^{3} \mathrm{~s}^{-1}\right)$.
Beside its unusual late start, the 2006 hydrology season confirmed the recent shifting trend of the hydrological regime. As indicated above, the local peak flow $\left(1890 \mathrm{~m}^{3} \mathrm{~s}^{-1}\right)$ was larger than the so-called "Guinean" peak flow $\left(1770 \mathrm{~m}^{3} \mathrm{~s}^{-1}\right)$, a situation that occurred 8 times in 16 years between 1991 and 2006, while it was observed only twice between 1929 and 1990. This results from two factors: i) as can be seen in Fig. 1, the rainfall deficit of 2006 was larger over the South-Western part of the Niger Basin than over its central and Eastern part, a situation that has been 

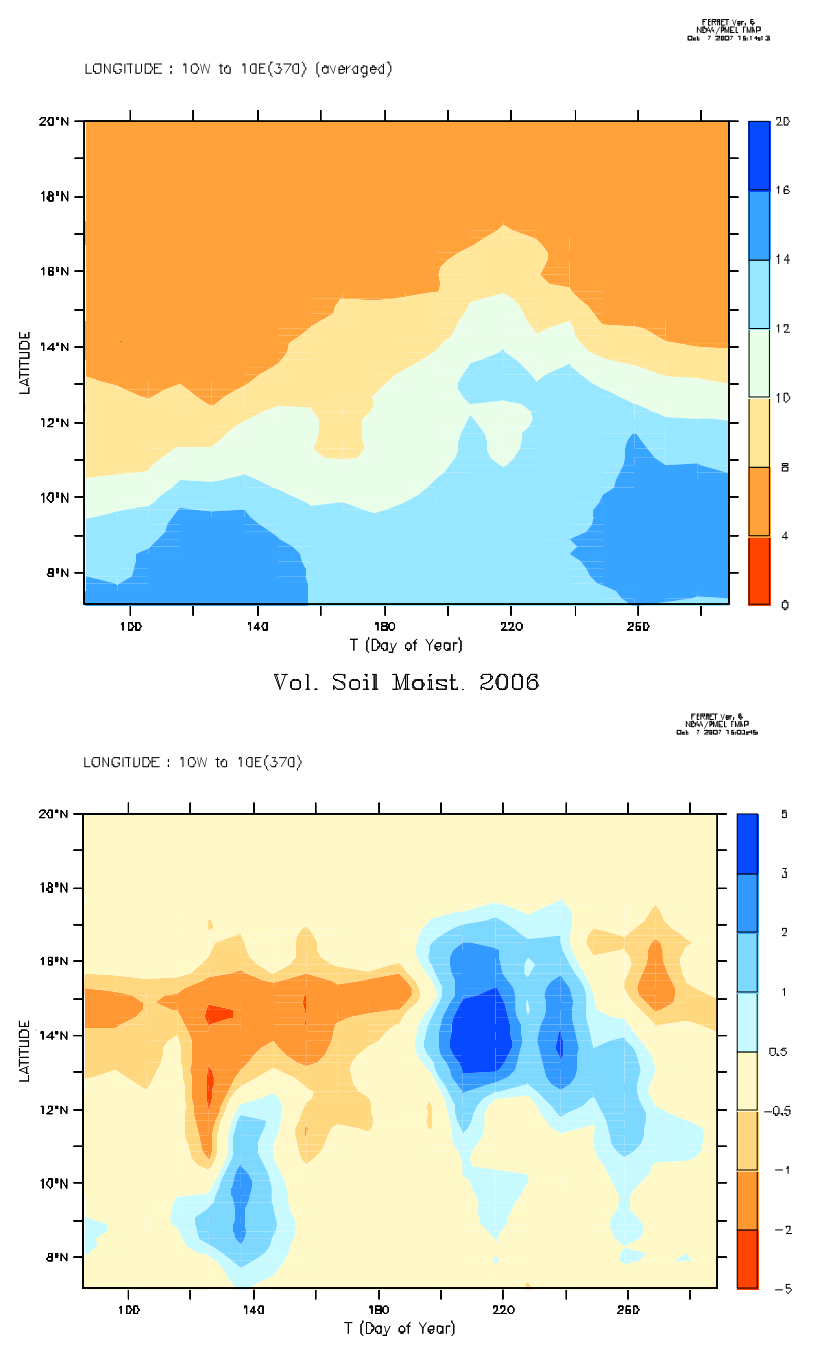
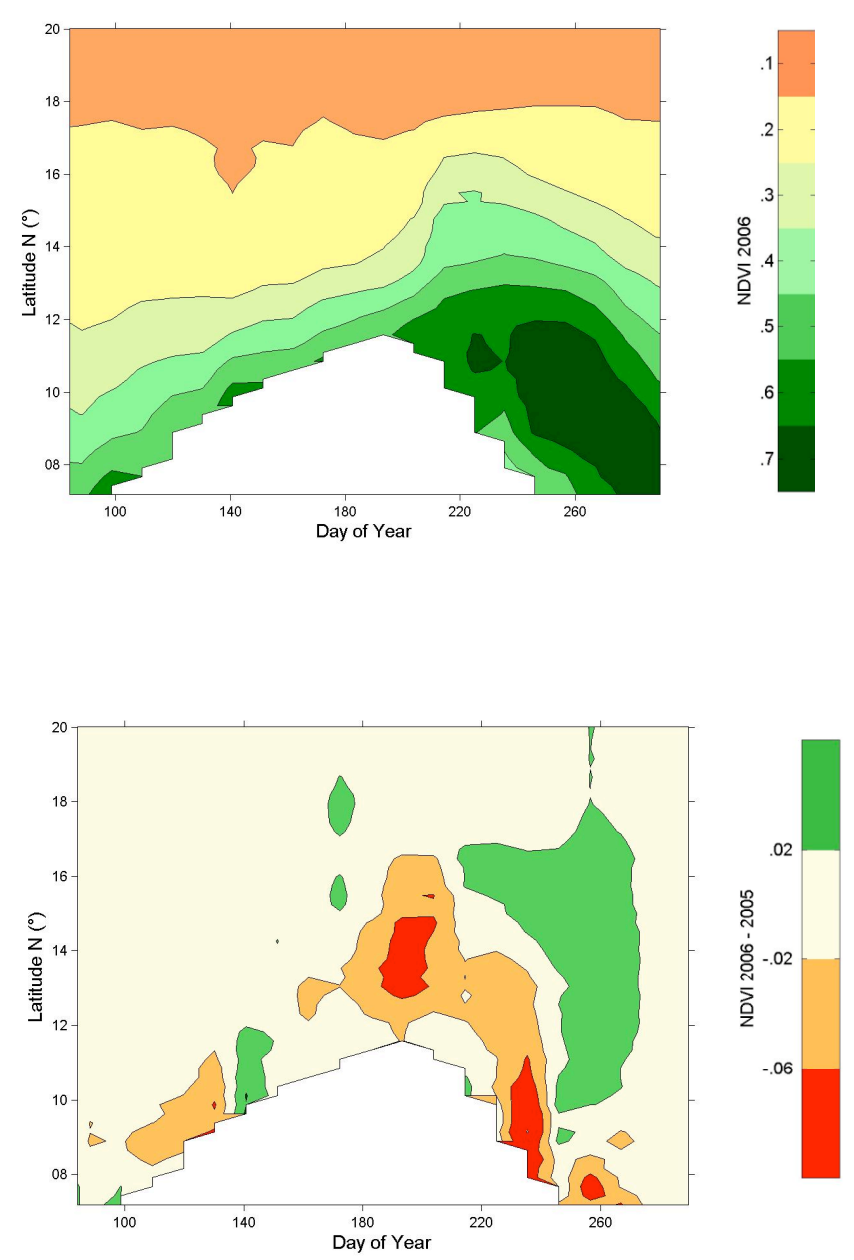

Fig. 24. Time-latitude diagram of 2006 (top) and 2006-2005 anomaly (bottom) of (left) surface soil moisture $\left(\%\right.$ of $\mathrm{m}^{3} \mathrm{~m}^{-3}$ ) and (right) NDVI, averaged between $10^{\circ} \mathrm{W}$ and $10^{\circ} \mathrm{E}$. Regions of persistent cloud contamination are shown in white on the NDVI plot. The x-axis labels are expressed in days from 1 January.

recurrent over the past 15 years; ii) due to the marked degradation of the vegetation in the Northern part of the basin, the runoff coefficients in this region have increased significantly since the 1980s, an equivalent rainfall thus producing comparatively more runoff over the regions contributing to the local peak flow of August than over the South Western regions contributing to the "Guinean" peak flow of December.

\subsection{Soil moisture and vegetation}

The unusual seasonal evolution of the rainfall in 2006 also had a significant impact on the land surface conditions. Figure 24 (top-left) shows time-latitude diagram of surface moisture in 2006 and Fig. 24 (bottom-left) compares the surface soil moisture of 2006 with that of 2005 . The soil moisture represents the first top $3 \mathrm{~cm}$. It is derived from AMSR-
E (Advanced Microwave Scanning Radiometer - Earth Observing System) using the approach of Njoku (2004), averaged over 10 days. The AMSR-E soil moisture products were calculated against field measurements over the Mali site for 2005 and have been shown to significantly capture the surface soil moisture dynamics with a correlation of $54 \%$ at the yearly scale (Gruhier et al., 2008). Figure 24 clearly shows that the latitude-time distribution of soil moisture over the Sahel was drastically different in 2006 compared with 2005. Although both 2005 and 2006 are considered to be close to average in terms of annual mean precipitation over the Sahel, strong differences in terms of temporal dynamics of precipitation have been reported. Figure 24 depicts a weak negative anomaly of surface soil moisture $\left(\sim-1 \% \mathrm{~m}^{3} \mathrm{~m}^{-3}\right)$ in 2006 over the Sahel until mid-July (Day of Year 195). This anomaly is consistent with the later monsoon arrival in 2006 
Table 1. Monthly mean net radiation $\left(\mathrm{W} \mathrm{m}^{-2}\right)$ at Agoufou (Mali, $15.2^{\circ} \mathrm{N}, 1.3^{\circ} \mathrm{W}$ ), comparing 2004 (dry year), 2005 (normal rainfall year) and 2006 (dry early monsoon, wet late monsoon). The shift in Rnet between a low energy July and high energy August in 2006 illustrates the dynamic response of Sahelian land surface.

\begin{tabular}{lccc}
\hline & 2004 & 2005 & 2006 \\
\hline July & 98 & 115 & 101 \\
August & 105 & 137 & 143 \\
\hline
\end{tabular}

compared to 2005. However it must be taken with care since it is in the range of uncertainty of the AMSR-E soil moisture products during the dry season (Gruhier et al., 2008). In contrast, the strong positive anomaly of surface soil moisture $\left(+3 \%\right.$ to $\left.+5 \% \mathrm{~m}^{3} \mathrm{~m}^{-3}\right)$ shown from late July to midSeptember ( $\sim$ Days of Year $200-250)$ is significant and it is consistent with the enhanced convective activity reported for late July to September 2006 (Fig. 2). A relatively drier period is depicted in AMSR-E surface soil moisture over Sahel in August 2006 between day 225 and 235, with lower values of the positive anomaly of soil moisture (Fig. 24). This signal, which shapes the monsoon intra-seasonal variability, is consistent with lower convective activity, as shown in Fig. 6 by the observed mid-August discontinuity in the OLR timelatitude field over the Sahel.

The distribution and seasonality of plants in the West African region is constrained by soil moisture in the root zone and hence rainfall. As a consequence, there is a dramatic gradient from the southern coastal area to the Sahara, which translates into a gradient in plant phenology. Plant canopies are mostly evergreen in the wettest areas (native forests or plantations), whereas the Sahel shows a very short growing season (herbaceous pastures and crops like millet). This strong latitudinal gradient in plant leaves duration and timing is seen as a "green wave" by satellite sensors like SPOT-VGT or TERRA-MODIS, which produce Normalized Difference Vegetation Index (NDVI e.g. Moulin et al., 1997). Figure 24 (right panels) displays the Hovmoeller plot of the NDVI from SPOT-VGT for 2006 (top) together with the difference between 2006 and 2005 (bottom). It depicts two very distinct periods: By mid July, a strong negative anomaly had developed between $12^{\circ} \mathrm{N}$ and $17^{\circ} \mathrm{N}$, which was caused by the delay in the Sahelian rainfall in 2006. Starting in midJuly and peaking by the end of July, ample rainfalls triggered the rapid growth of Sahelian grasses and crops, in such a way that the anomaly was reversed. A positive anomaly then occured, as early as August in Northern Sahel but not before September at $10^{\circ} \mathrm{N}$. Further South, the vegetation anomaly remained negative throughout the rain season.

Such a strong intraseasonal variability of soil moisture and vegetation conditions translates into important surface properties like the surface radiation and turbulent fluxes

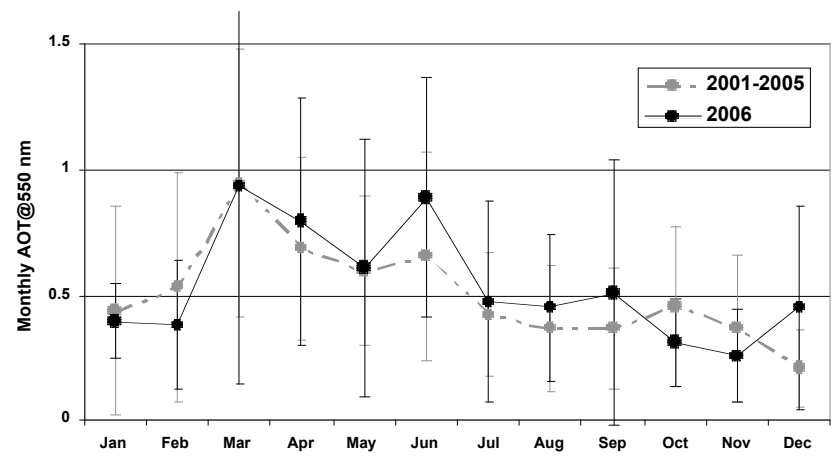

Fig. 25. Monthly mean aerosol optical thicknesses measured at $550 \mathrm{~nm}$ in Banizoumbou (Niger, $13.31^{\circ} \mathrm{N} / 2.66^{\circ} \mathrm{E}$; see its location on Fig. 1) from 2000 to 2005 and in 2006 (the monthly means are computed from daily averages available on the AERONET web site http://aeronet.gsfc.nasa.gov/; for the 2006 data set the errors bars represent the monthly standard deviation; for the 2000-2005 average, the error bars represent the average monthly standard deviation).

(Guichard et al., 2008). Surface net radiation in the Sahel strongly depends on plant phenology because plant evapotranspiration cools the surface (less long wave losses) whereas plant albedo is usually lower than soil albedo (Samain et al., 2008). Table 1 compares the surface net radiation measured at Agoufou $\left(15.2^{\circ} \mathrm{N}-1.3^{\circ} \mathrm{W}\right)$ for July and August for years 2004 (dry year), 2005 (normal rainfall year) and 2006 (dry early monsoon, wet late monsoon). Because of the strong negative soil moisture and vegetation anomalies of mid-July, the early 2006 monsoon season net radiation is close to that of 2004. By contrast, the subsequent rapid development of plants in August resulted in the largest August net radiation being in 2006. These numbers exemplify the rapid dynamic response of land surface and its potential for feedbacks in the monsoon system (Nicholson, 2000). Figure 24 implies that such changes in the surface energy budget were manifested at the large scale in 2006 (Samain et al., 2008). In terms of plant productivity and food security, the large rainfall of the late 2006 monsoon season ensured above average crops and livestock conditions in the Sahel, as opposed to what happened in 2004 (CIILS, 2007).

\section{Saharan aerosols}

The "Sahelian belt" is known as a region where mineral dust content is among the highest in the world (Prospero et al., 2002). The implementation in the 1990s of several stations of the AERONET network of sunphotometer (http: //aeronet.gsfc.nasa.gov/) has provided a high quality and representative data set to support analysis of the seasonal cycle of the vertically integrated amount of aerosol over the Sahelian region. From the measurements of the different stations located over West Africa, mineral dust is the main contributor 
to the aerosol optical thicknesses (AOTs) during the wet season. At the Banizoumbou station $(\sim 70 \mathrm{~km}$ northeast of $\mathrm{Ni}$ amey), the measured AOTs exhibits a low spectral dependence induced by coarse particles, indicating the predominance of mineral dust. The monthly mean AOTs measured in 2006 have been compared to the mean monthly AOTs between 2000 and 2005 (Fig. 25). The mean 2000-2005 AOT displays a typical seasonal cycle characterized by a maximum in the spring and especially in March, and a minimum in the wet summer season. A secondary maximum is observed in June before the rainy season and a secondary minimum is detected during the dry season in December. The spring maximum is due to intense dust emissions over the Sahara that can be efficiently transported in the Sahel due to the southern position of the ITD. Saharan dust emissions are a minimum in winter (D'Almeida, 1986), which explains the low AOTs measured in December. Even if dust emissions are active in the western part of the Sahara during summer (Marticorena and Bergametti, 1996) the AOTs tend to be lower in summer due to the wash out of dust particles by precipitation. The monthly AOTs measured in 2006 follows a similar seasonal cycle to that of the 2000-2005 average but several distinctive features can be highlighted. As confirmed by the results from the Special Observing Period performed during the dry season (SOP0, January-February 2006), the aerosol content in winter was abnormally low compared to the previous five years. In contrast to this, the mineral dust content in June was higher by a factor of 1.9 than the five year average AOTs. At this time of the year, high AOTs can either be due to Saharan dust transported in the Saharan Air Layer or to local dust emissions lifted by convective systems. Indeed mineral dust can be produced by local erosion during the passage of convective systems, for which the surface wind velocity exceeds the erosion threshold. Local aeolian erosion was continuously monitored at the Banizoumbou station from May to August. The occurrence of local erosion events can be compared to average occurrence of such events averaged over the period 1995-1998 (J. L. Rajot, personal communication). The number of erosion events recorded in 2006 was similar to the average number of events recorded between 1995 and 1998. It progressively increased from the beginning of May until the second half of June due to the increased occurrence of convective systems and decreased until the end of June because the soil moisture and the growing the vegetation tends to prevent or limit local aeolian erosion. In 2006 , the temporal distribution of local erosion events tended to be shifted later in the wet season, suggesting a later inhibition of local dust emissions by soil moisture and vegetation. This may reflect the observed 10-day delay in the occurrence of fast-moving MCS activity in 2006 relative to the mean 1996-2006 convective activity.

In addition to the AOTs and the wet and total aerosol deposition, the surface concentration of particulate matter lower than $10 \mu \mathrm{m}\left(\mathrm{PM}_{10}\right)$ was monitored at three stations located in M'Bour (Senegal, $16.96^{\circ} \mathrm{W}$ ), Cinzana (Mali, $5.93^{\circ} \mathrm{W}$ )

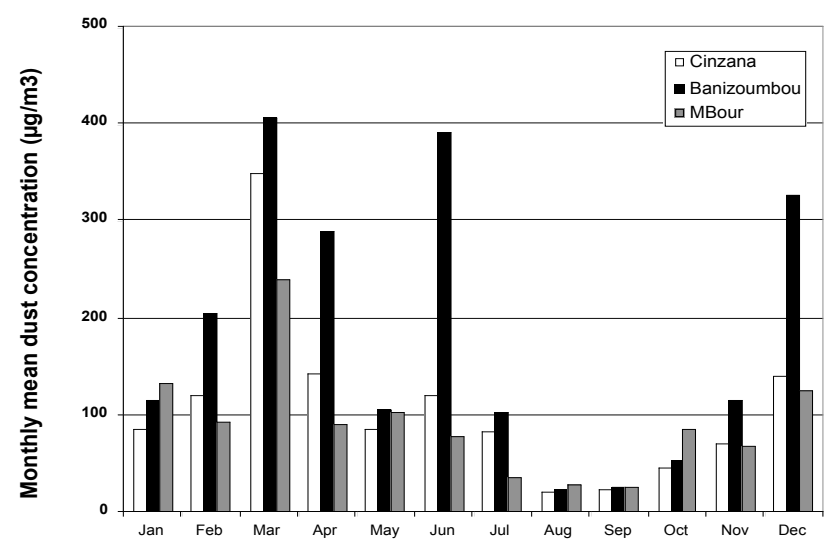

Fig. 26. Monthly mean atmospheric concentration of particulate matter lower than $10 \mu \mathrm{m}\left(\mathrm{PM}_{10}\right)$ measured along the Sahelian Dust Transect (M'Bour, Senegal, $14.25^{\circ} \mathrm{N} / 16.96^{\circ} \mathrm{W}$; Cinzana, Mali, $13.28^{\circ} \mathrm{N} / 5.93^{\circ} \mathrm{W}$ and Banizoumbou, Niger, $\left.13.31^{\circ} \mathrm{N} / 2.66^{\circ} \mathrm{E}\right)$ in 2006 (see their location on Fig. 1). (the monthly means have been computed from the raw daily mean concentrations available on the AMMA data base using on wind direction criterions to select only dust transport wind sectors).

and Banizoumbou (Niger, $2.66^{\circ} \mathrm{W}$ ), composing the so-called "Sahelian Dust Transect". A selection of the 5 min raw data has been examined using the wind direction as a criterion to select sectors that can be only associated with mineral dust transport. The seasonal cycle of the monthly mean surface concentration (Fig. 26) is comparable but more accentuated than the seasonal cycle of the AOTs. In Banizoumbou, for example, the ratio between the monthly surface concentrations measured in March and in August is higher than 17, while it is only 2 for the monthly mean AOTs. This can be explained by the persistence of high altitude transport of Saharan dust over the Sahel in the summer that cannot be recorded by the surface level sampling. Future analysis of lidar measurements should help address this issue. A similar seasonal pattern of the surface concentrations is observed at the three stations, i.e. from Niger to Senegal with a gradient in the monthly concentrations that tends to decrease from East to West. In summer, the concentrations are higher in Senegal than in Niger and Mali, suggesting a high altitude transport of mineral dust emitted from the southwestern sources of the Sahara over the north tropical Atlantic ocean (Fig. 25).

The analysis of the mean daily concentration and the associated standard deviation reveals a huge variability from annual to daily timescales (Fig. 27). In Banizoumbou, the daily concentration has a range that is over three orders of magnitude and exhibits a very high daily variability. The minimum daily concentrations in August can be as low as $10 \mu \mathrm{gm}^{-3}$ while daily concentrations higher than $1 \mathrm{gm}^{-3}$ have been measured during the dry season in February, March and December but also at the beginning of the wet season in June (note that the limit for air quality control in Europe for $\mathrm{PM}_{10}$ 


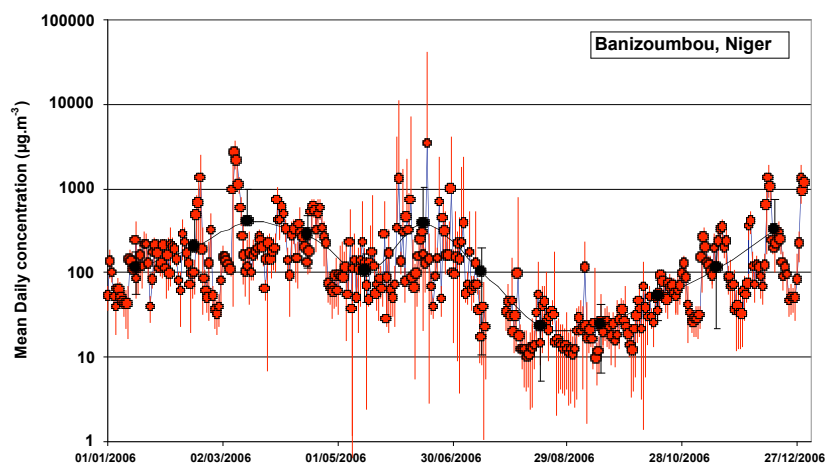

Fig. 27. Daily mean atmospheric concentrations of particulate matter lower than $10 \mu \mathrm{m}\left(\mathrm{PM}_{10}\right)$ (red dots) and daily standard deviations (red bars) measured in Banizoumbou (Niger, $13.31^{\circ} \mathrm{N} / 2.66^{\circ} \mathrm{E}$; see its location on Fig. 1) in 2006. The black dots represent the monthly means and standard deviations (note that the daily mean concentrations have been computed based on a selection of raw data using wind direction criterions to select only dust transport wind sectors).

daily concentration is $50 \mu \mathrm{gm}^{-3}$; this limit was exceeded for more than $40 \%$ of the year 2006 in Banizoumbou). During the dry season the daily standard deviation is lower or comparable to the daily mean concentration. In summer, and especially at the beginning of the wet season, the daily range can reach one or two orders of magnitude. Sudden and tremendous increases of the surface concentration are measured during the passage of convective systems that can be followed by very low concentrations due to the wash out of the emitted dust by the precipitation. Another feature distinguishing the dry and wet seasons is that the high concentration events in the dry season are generally recorded at two or three of the sampling stations, highlighting the continental to regional scale of the Saharan dust transport events. In contrast to this, the high daily concentrations measured in Banizoumbou are not phased with those measured in Cinzana or M'Bour, underlining the local influence of the mesoscale convective systems on the local dust production and transport.

\section{Gas phase chemistry and large scale ozone distribution}

The AMMA 2006 summer monsoon field campaign also produced the first detailed, in-situ, characterisation of the tropospheric chemical composition over West Africa. Five research aircraft (three based in Niamey, Niger: NERC BAe146, CNRS Falcon and ATR; and two in Ouagadougou, Burkina Faso: DLR Falcon and Geophysica M55) made comprehensive chemical measurements from the boundary layer to the lower stratosphere (around $50 \mathrm{hPa}$ ), from $2^{\circ} \mathrm{N}$ to $20^{\circ} \mathrm{N}$, and between $6^{\circ} \mathrm{W}$ and $6^{\circ} \mathrm{E}$. The aircraft were equipped with instruments to make measurements of ozone $\left(\mathrm{O}_{3}\right)$, many of its precursor species (e.g. carbon monoxide

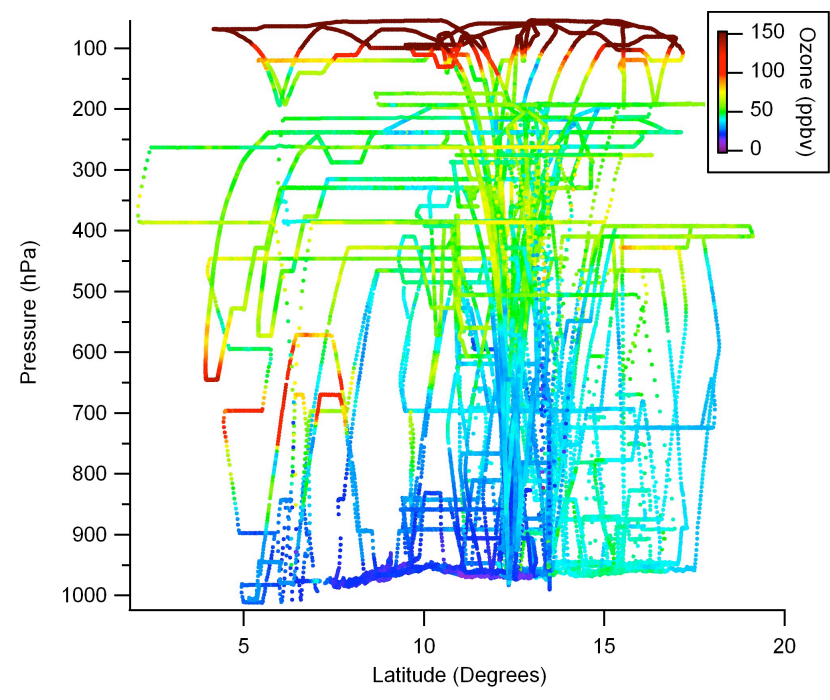

Fig. 28. Flight tracks for the BAe-146, the DLR Falcon, the French Falcon and the M55 between 20 July and 21 August plotted as a function of latitude and altitude and coloured by the ozone concentration. Note that the ozone concentrations above $100 \mathrm{hPa}$ are off the colour scale, extending up to $1700 \mathrm{ppb}$.

$(\mathrm{CO})$, nitrogen oxides $\left(\mathrm{NO}_{\mathrm{x}}\right)$ and volatile organic compounds (VOCs), as well as photochemical products (e.g. radicals species and oxygenated VOCs (OVOCs).

Previous in-situ observations in this region at this time of year have been confined to the MOZAIC programme, which involved measurements on commercial aircraft flying in the upper troposphere (Sauvage et al., 2007), with vertical profiles as they descended and ascended into airports at Abidjan, Ivory Coast and Lagos, Nigeria (Sauvage et al., 2005). The MOZAIC measurements have been limited to $\mathrm{O}_{3}, \mathrm{CO}$ and total odd nitrogen $\left(\mathrm{NO}_{\mathrm{y}}\right)$. Otherwise measurements during the dry season have been made around the Ivory Coast as part of TROPOZ (December 1987, January 1991) (Jonquieres et al., 1998) and DECAFE (January 1991) (Delmas et al., 1995), and from Niamey as part of AMMA DABEX (January and February 2006). Other measurements in Central and Southern Africa have also focussed on the dry season when there is widespread biomass burning (Andreae et al., 1992; Cros et al., 1992; Delmas et al., 1999; Fontan et al., 1992).

Figure 28 shows the flight tracks of most of the AMMA 2006 monsoon chemistry flights made by the BAe-146, the DLR Falcon, the French Falcon and the M55 aircraft between 20 July and 21 August plotted as a function of latitude and altitude and coloured by the $\mathrm{O}_{3}$ concentration. This period extends from the beginning of the full-developed monsoon season, covers a high convective phase around the beginning of August and ends with a weak convective phase near midAugust (Figs. 6 and 22). A number of features evident in the $\mathrm{O}_{3}$ distribution can be related to the dynamics of the region. There is a general vertical gradient with concentrations 
declining towards the surface. A sharp gradient is observed around $100 \mathrm{hPa}$, with concentrations up to $1700 \mathrm{ppb}$ above in the lower stratosphere, whilst concentrations in the troposphere rarely exceed $100 \mathrm{ppb}$.

The exceptions are a number of air masses that were observed between 750 and $550 \mathrm{hPa}$ and between $4^{\circ} \mathrm{N}$ and $8^{\circ} \mathrm{N}$ which were identified by tracers, such as acetonitrile, as having been impacted by biomass burning. These had been transported into West Africa in the easterly flow of the southern hemispheric AEJ (see this wind core along $5^{\circ} \mathrm{S}$ on Fig. 4) and appear to have been impacted by biomass burning which took place in southern Africa (Mari et al., 2008). Similar features over West Africa have been observed previously in the MOZAIC vertical profiles over Lagos (Sauvage et al., 2005) and in ozone sonde data from Cotonou collected as part of AMMA, and are part of a wider phenomenon observed elsewhere in Africa (Nganga et al., 1996).

The variability in $\mathrm{O}_{3}$ in the upper troposphere is associated with the deep convection within the ITCZ, lifting $\mathrm{O}_{3}$ poor air from near the surface to higher altitudes. Subsidence associated with this convection will transport $\mathrm{O}_{3}$ rich air to lower altitudes. The deep convective events are often associated with lightning which produces $\mathrm{NO}_{\mathrm{x}}$, mostly in the upper troposphere, which may lead to $\mathrm{O}_{3}$ production.

The most noticeable gradient in the lower troposphere is a latitudinal one, with lower concentrations to the south and a sharp gradient around $13^{\circ} \mathrm{N}-14^{\circ} \mathrm{N}$. The ITD is located closer to $20^{\circ} \mathrm{N}$ (Fig. 3) so the reason for the pattern in the $\mathrm{O}_{3}$ does not appear to be simply a function of the south westerly monsoon air being lower in $\mathrm{O}_{3}$ than the north easterly Harmattan. There is, however, a strong vegetation gradient around $12^{\circ} \mathrm{N}-13^{\circ} \mathrm{N}$ (Fig. 24), with substantial tree cover to the south and bare soil and scrubland to the north. The lower $\mathrm{O}_{3}$ to the south is therefore likely to be at least partly due to rapid deposition to trees (Cros et al., 2000). Biogenic emissions of ozone precursors (e.g. isoprene from trees and $\mathrm{NO}_{\mathrm{x}}$ from soils) will also be effected by the latitudinal vegetation and soil moisture gradients (Fig. 24).

The ozone budget is being examined in detail through the AMMA programme, using the comprehensive observational data set, chemical box models, and chemical transport models and will be the subject of further papers.

\section{Conclusion}

The 2006 African summer monsoon was characterized by near-normal convective activity except for a large-scale rainfall excess north of $15^{\circ} \mathrm{N}$. The dynamical monsoon onset occurred around 25 June (near the mean date) with a transition period characterized by an overall weakening of convection over West Africa which lasted approximately from 25 June to 10 July. Convection began to increase significantly over the Sahel from the 5 July, that is with about a 10-day delay with respect to the mean. It is suggested here that this delay may be explained either by local air-sea interactions in the Gulf of Guinea (the equatorial upwelling developed with a 10-15day lag in 2006 compared to 2005) or by a remote forcing due to the occurrence of an MJO-type event in the tropical latitudes (inducing a Kelvin wave type atmospheric teleconnection). The monsoon winds were weaker than the mean in June and increased after to produce stronger westerly inflow of moisture in August and September. The AEJ was stronger than the mean from June to August, and the TEJ was weaker in June and stronger in August and September. At the synoptic time scale, twenty-seven African easterly waves were detected and highest activity occurred in August-September. Seven of the AEWs were associated with tropical cyclones in the Atlantic. The activity of equatorial Kelvin waves was high in June. Nine events of dry extra-tropical air intrusions also occurred during the season that appeared to be modulated at two main time scales, the synoptic (by AEWs) and intra-seasonal (10-20 days and 40-50 days) scales. The delay of the monsoon convective activity had big impacts on continental hydrology and vegetation dynamics. The timing of Niger River discharge had a mean delay of one month but the 2006 discharge caught up with the 2005 value by midAugust. Similarly the late 2006 monsoon arrival led to negative soil moisture anomalies over the Sahel from April to mid-July but this was followed by strong positive anomalies in August-September, inducing similar vegetation cover anomalies and large changes in the surface energy budget. The mineral dust content in the Sahelian belt, the main contributor to the AOTs, is among the highest in the world. In 2006 the monthly AOTs followed a seasonal cycle similar to the mean, except for higher values in June, and a decrease shifted later in the wet season revealing a later inhibition of local dust emission due to late vegetation development. Finally the $\mathrm{O}_{3}$ distribution is closely related to the dynamics of the region, in particular deep convection lifting $\mathrm{O}_{3}$ deficient air from near the surface to the upper troposphere, as well as the surface characteristics (soil moisture and vegetation) which influence biogenic emissions. Tracers from biomass burning which took place in southern Africa were also detected in the mid-levels of the troposphere between $4^{\circ} \mathrm{N}$ and $8^{\circ} \mathrm{N}$.

Acknowledgements. We are thankful to NOAA-CIRES Climate Diagnostics Center (Boulder, CO) for providing the NCEP/NCAR Reanalysis and operational analysis datasets and the Interpolated OLR dataset from their Web site at http://www.cdc.noaa.gov, AGRHYMET for the rainfall data, M. C. Wheeler of Bureau of Meteorology Research Centre for the availability of his realtime analysis of equatorial convectively-coupled waves during this AMMA intensive campaign (http://www.bom.gov.au/bmrc/clfor/ cfstaff/matw/maproom/OLR_modes/index.htm), the NASA Goddard Space Flight Center for the GPCP data (http://precip.gsfc. nasa.gov), the Snow and Ice Distributed Active Archive at the National Snow and Ice Data Center for the AMSR-E data, the SPOTVEGETATION archive system (http://free.vgt.vito.be), the Facility for Airborne Atmospheric Measurements (FAAM) for providing the 
airborne ozone data, the AERONET Network (http://aeronet.gsfc. nasa.gov) and in particular Didier Tanré for providing the longterm aerosol optical thickness measurements. The GPS network has taken advantage of the scientific, technical and administrative support in the installation and maintenance of the National Meteorological Services of Mali, Niger, Burkina-Faso, Ghana, the Abomey-Calavi University in Benin, ACMAD and ASECNA in Niger, IRD, IGN, METEO-FRANCE and CNRS. ACMAD is also thanked for his operational forecast activities during this AMMA intensive campaign. We also thank all the leaders of the AMMA-EOP task teams for providing data of high values, especially L. Descroix and collaborators in charge of the Niger mesoscale site, E. Mougin and F. Timouk in charge of the Agoufou site, and Jean-Louis Rajot and Bernadette Chatenet in charge of the Sahelian Dust Transect. C. D. Thorncroft was supported by NSF Grant ATM0507976. Based on French initiative, AMMA was built by an international scientific group and is currently funded by a large number of agencies, especially from France, UK, US and Africa. It has been the beneficiary of a major financial contribution from the European Community's Sixth Framework Research Programme. Detailed information on scientific coordination and funding is available on the AMMA International website http://www.amma-international.org.

Topical Editor F. D'Andrea thanks two anonymous referees for their help in evaluating this paper.

\section{References}

Adler, R. F., Huffman, G. J., Chang, A., Ferraro, R., Xie, P., Janowiak, J., Rudolf, B., Schneider, U., Curtis, S., Bolvin, D., Gruber, A., Susskind, J., Arkin, P., and Nelkin, E.: The Version 2 Global Precipitation Climatology Project (GPCP) Monthly Precipitation Analysis (1979-Present), J. Hydrometeor., 4, 11471167, 2003.

Andreae, M. O., Chapuis, A., Cros, B., Fontan, J., Helas, G., Justice, C., Kaufman, Y. J., Minga, A., and Nganga, D.: Ozone and Aitken nuclei over equatorial Africa - Airborne observations during Decafe-88, J. Geophys. Res.-Atmos., 97, 61376148, 1992.

Avila, L. A. and Pasch, R. J.: Atlantic tropical systems of 1991, Mon. Weather Rev., 120, 2688-2696, 1992.

Berry, G., Thorncroft, C., and Hewson, T.: African easterly waves during 2004 - Analysis using objective techniques, Mon. Weather Rev., 135, 1251-1267, 2007.

Bevis, M., Businger, S., Herring, T. A., Rocken, C., Anthes, R. A., and Ware, R. H.: GPS Meteorology: Remote Sensing of the Atmospheric Water Vapor Using the Global Positioning System, J. Geophys. Res., 97, 15 787-15 801, 1992.

Bock, O., Guichard, F., Janicot, S., Lafore, J. P., Bouin, M. N., and Sultan, B.: Multiscale analysis of precipitable water vapor over Africa from GPS data and ECMWF analyses, Geophys. Res. Lett., 34, L09705, doi:10.1029/2006GL028039, 2007.

Bourles, B., Brandt, P., Caniaux, G., Dengler, M., Gouriou, Y., Key, E., Lumpkin, R., Marin, F., Molinari, R. L., and Schmid, C.: African Monsoon Multidisciplinary Analysis (AMMA): Special measurements in the tropical Atlantic, CLIVAR Newsletter Exchanges, 41, 7-9, 2007.

Cros, B., Fontan, J., Minga, A., Helas, G., Nganga, D., Delmas, R., Chapuis, A., Benech, B., Druilhet, A., and Andreae, M. O.: Vertical profiles of ozone between 0 and 400 meters in and above the
African equatorial forest, J. Geophys. Res.-Atmos., 97, $12877-$ $12887,1992$.

D'Almeida, G. A.: A model for Saharan dust transport, J. Climate Appl. Meteorol., 25, 903-916, 1986.

Delmas, R., Lacaux, J. P., Menaut, J. C., Abbadie, L., Leroux, X., Helas, G., and Lobert, J.: Nitrogen compound emission from biomass burning in tropical African savanna Fos/Decafe-1991 Experiment (Lamto, Ivory Coast), J. Atmos. Chem., 22, 175193, 1995.

Delmas, R., Druilhet, A., Cros, B., Durand, P., Delon, C., Lacaux, J. P., Brustet, J. M., Serca, D., Affre, C., Guenther, A., Greenberg, J., Baugh, W., Harley, P., Klinger, L., Ginoux, P., Brasseur, G., Zimmerman, P. R., Gregoire, J. M., Janodet, E., Tournier, A., Perros, P., Mrion, T., Gaudichet, A., Cachier, H., Ruellan, S., Masclet, P., Cautenet, S., Poulet, D., Biona, C. B., Nganga, D., Tathy, J. P., Minga, A., Loemba-Ndembi, J., and Ceccato, P.: Experiment for regional sources and sinks of oxidants (EXPRESSO): An overview, J. Geophys. Res.-Atmos., 104, 30 609$30624,1999$.

Diedhiou, A., Janicot, S., Viltard, A., de Felice, P., and Laurent, H.: Easterly wave regimes and associated convection over West Africa and the tropical Atlantic : Results from NCEP/NCAR and ECMWF reanalyses, Clim. Dynam., 15, 795-822, 1999.

Fontan, J., Druilhet, A., Benech, B., Lyra, R., and Cros, B.: The Decafe Experiments - Overview and meteorology, J. Geophys. Res.-Atmos., 97, 6123-6136, 1992.

Grist, J. P. and Nicholson, S. E.: A study of the dynamical factors influencing the rainfall variability in the West African Sahel, J. Climate, 14, 1337-1359, 2001.

Gruhier, C., de Rosnay, P., Kerr, Y., Mougin, E., Ceschia, E., Calvet, J. C., and Richaume, P.: Evaluation of AMSR-E soil moisture product based on ground measurements over temperate and semi-arid regions, Geophys. Res. Lett., 35, L10405, doi:10.1029/2008GL033330, 2008.

Guichard, F., Kergoat, L., Mougin, E., Timouk, F., Baup, F., Hiernaux, P., and Lavenu, L.: Surface thermodynamics and radiative budget in the Sahelian Gourma: seasonal and diurnal cycles, J. Hydrol., accepted, 2008.

Jonquieres, I., Marenco, A., Maalej, A., and Rohrer, F.: Study of ozone formation and transatlantic transport from biomass burning emissions over West Africa during the airborne tropospheric ozone campaigns TROPOZ I and TROPOZ II, J. Geophys. Res.Atmos., 103, 19 059-19073, 1998.

Kalnay, E., Kanamitsu, M., Kistler, R., Collins, W., Deaven, D., Gandin, L., Iredell, M., Saha, S., White, G., Woolen, J., Zhu, Y., Chelliah, M., Ebisuzaki, W., Higgins, W., Janowiak, J., Mo, K. C., Ropelewski, C., Wang, J., Leetma, A., Reynolds, R., Jenne, R., and Joseph, D.: The NCEP/NCAR 40-year reanalysis project, B. Am. Meteorol. Soc., 77, 437-471, 1996.

Lamb, P. J.: Large-scale tropical surface circulation patterns associated with Subsaharan weather anomalies, Tellus, 30, 240-251, 1978a.

Lamb, P. J.: Case studies of tropical Atlantic surface circulation patterns during recent sub-Saharan weather anomalies: 1967 and 1968, Mon. Weather Rev., 106, 482-491, 1978 b.

Lavaysse C., Diedhiou, A., Laurent, H., and Lebel, T.: African Easterly Waves and convective activity in wet and dry sequences of the West African Monsoon, Clim. Dynam., 27, 319-332, 2006.

Liebmann, B. and Smith, C. A.: Description of a complete (inter- 
polated) outgoing long-wave radiation dataset, B. Am. Meteorol. Soc., 77, 1275-1277, 1996.

Mathon, V., Laurent H., and Lebel, T.: Mesoscale convective system rainfall in the Sahel, J. Appl. Meteor., 41, 1081-1092, 2002.

Matthews, M.: Intraseasonal variability over tropical Africa during northern summer, J. Climate, 17, 2427-2440, 2004.

Mari, C. H., Cailley, G., Corre, L., Saunois, M., Attié, J. L., Thouret, V., and Stohl, A.: Tracing biomass burning plumes from the Southern Hemisphere during the AMMA 2006 wet season experiment, Atmos. Chem. Phys., 8, 3951-3961, 2008, http://www.atmos-chem-phys.net/8/3951/2008/.

Marticorena, B. and Bergametti, G.: Two-years simulations of seasonal and interannual changes of the Saharan dust emissions, Geophys. Res. Lett., 23, 1921-1924, 1996.

Mekkonen, A., Thorncroft, C. D., Aiyyer, A. R., and Kiladis, G. N.: Convectively coupled Kelvin waves over tropical Africa during the boreal summer: Structure and variability, J. Climate, in press, 2008.

Morel, C. and Sénési, S.: A climatology of mesoscale convective systems over Europe using satellite infrared imagery. I: Methodology, Q. J. Roy. Meteorol. Soc., 128, 1953-1992, 2002.

Moulin, S., Kergoat, L., Viovy, N., and Dedieu, G.: Global-Scale of Vegetation Phenology Using NOAA/AVHRR Satellite Measurements, J. Climate, 10, 1154-1170, 1997.

Mounier, F. and Janicot, S.: Evidence of two independent modes of convection at intraseasonal timescale in the West African summer monsoon, Geophys. Res. Lett., 31, L16116, doi:10.1029/2004GL020665, 2004.

Mounier, F. and Janicot, S.: 40-day periodicity mode of variability in the West and Central African monsoon, AMS Conference on Climate Variability and Change, San Antonio, TX, 14-18 January 2007.

Mounier, F., Kiladis, G., and Janicot, S.: Analysis of the dominant mode of convectively coupled Kelvin waves in the West African monsoon, J. Climate, 20, 1487-1503, 2007.

Mounier, F., Janicot, S., and Kiladis, G.: The West African monsoon dynamics. Part III: The quasi-biweekly zonal dipole, J. Climate, 21, 1911-1928, 2008.

Nganga, D., Minga, A., Cros, B., Biona, B., Fishman, J., and Grant, W. B.: The vertical distribution of ozone measured at Brazzaville, Congo, during TRACE A, J. Geophys. Res.-Atmos., 101, 24 095-24 103, 1996.

Nicholson, S. E.: Land surface processes and Sahel climate, Rev. Geophys., 38, 117-139, 2000.

Njoku, E.: Updated daily AMSR-E/Aqua daily L3 surface soil moisture, interpretive parameters and QC EASE-Grids, March to June 2004, Boulder, CO, USA: National Snow and Ice Data Center, Digital Media, 2004.

Okomura, Y. and Xie, S. P.: Interaction of the Atlantic equatorial cold tongue and the African monsoon, J. Climate, 17, 35893602, 2004.

Parker, D., Fink, A., Janicot, S., Ngamini, J. B., Douglas, M., Afiesimama, E., Agusti-Panareda, A., Beljaars, A., Dide, F., Diedhiou, A., Lebel, T., Polcher, J., Redelsperger, J. L., Thorncroft, C. D., and Wilson, G. A.: The AMMA radiosonde program and its implications for the future of atmospheric monitoring over Africa, B. Am. Meteorol. Soc., 89, 1015-1027, 2008.

Pierrehumbert, R. T. and Roca, R.: Evidence for control of Atlantic subtropical humidity by large scale advection, Geophys.
Res. Lett., 25, 4537-4540, 1998.

Prospero, J. M., Ginoux, P., Torres, O., Nicholson, S. E., and Gill, T. E.: Environmental characterization of global sources of atmospheric soil dust identified with the Nimbus 7 Total Ozone Mapping Spectrometer (TOMS) absorbing aerosol product, Rev. Geophys., 40(1), 1-31, 2002.

Redelsperger, J. L., Parson, D. B., and Guichard, F.: Recovery processes and factors limiting cloud-top height following the arrival of a dry intrusion observed during TOGA-COARE, J. Atmos. Sci., 59, 2438-2457, 2002.

Redelsperger, J.-L., Thorncroft, C., Diedhiou, A., Lebel, T., Parker, D., and Polcher, J.: African Monsoon Multidisciplinary Analysis (AMMA): An International Research Project and Field Campaign, B. Am. Meteorol. Soc., 87, 1739-1746, 2006.

Reed, R. J., Norquist, D. C., and Recker, E. E.: The structure and properties of African wave disturbances as observed during Phase III of GATE, Mon. Weather Rev., 105, 17-33, 1977.

Roca, R., Lafore, J. P., Piriou, C., and Redelsperger, J. L.: Extratropical dry air intrusions into the West African Monsoon midtroposphere: an important factor for the convective activity over Sahel, J. Atmos. Sci., 62, 390-407, 2005a.

Roca, R., Brogniez, H., and Picon, L.: Variability of dry air in the mid-troposphere over the last 20 years: Satellite and trajectory climatologies. AMMA First International Conference, Dakar, Senegal, 28 November-4 December 2005b.

Roca, R. and Deme, A.: Dry intrusions in the African monsoon mid-troposphere during the AMMA experiment. Proceedings on the "Celebrating the Monsoon" Conference, Bangalore, India, in press, 2008.

Samain, O., Kergoat, L., Hiernaux, P., Guichard, F., Mougin, E., Timouk, F., and Lavenu, F.: Variability of Sahelian albedo from in situ and MODIS data, J. Geophys. Res., 113, D14119 doi:10.1029/2007JD009174, 2008.

Sauvage, B., Thouret, V., Cammas, J. P., Brioude, J., Nedelec, P., and Mari, C.: Meridional ozone gradients in the African upper troposphere, Geophys. Res. Lett., 34(3), L03817, doi:10.1029/2006GL028542, 2007.

Sauvage, B., Thouret, V., Cammas, J.-P., Gheusi, F., Athier, G., and Nédélec, P.: Tropospheric ozone over Equatorial Africa: regional aspects from the MOZAIC data, Atmos. Chem. Phys., 5, 311335, 2005, http://www.atmos-chem-phys.net/5/311/2005/.

Sultan, B. and Janicot, S.: The West African monsoon dynamics. Part II: The "pre-onset" and the "onset" of the summer monsoon, J. Climate, 16, 3407-3427, 2003.

Taylor, C., Kergoat, L., and de Rosnay, P.: Land Surface - Atmosphere Interactions During the AMMA SOP, Clivar Exchanges NewsLetter, AMMA special issue, 41, 20-21, 2007.

Thorncroft, C. D. and Blackburn, M.: On the maintenance of the African Easterly Jet, Q. J. Roy. Meteorol. Soc., 125, 763-786, 1999.

Thorncroft, C. D. and Hodges, K.: African easterly waves and its relationship to Atlantic tropical cyclone activity, J. Climate, 14, 1166-1179, 2000.

Tomasini, M. , Lafore, J. P., Piriou, C., Roca, R., Ramage, R., Laurent, H., Morel, C., and Senesi, S.: Atlas on a climatology of West African Mesoscale Convective Systems, AMMA European Deliverable, 2006.

Torrence, C. and Compo, G. P.: A practical guide to Wavelet Analysis, B. Am. Meteorol. Soc., 79, 61-78, 1998. 